Article

\title{
Provenance and Implication of Carboniferous-Permian Detrital Zircons from the Upper Paleozoic, Southern Ordos Basin, China: Evidence from U-Pb Geochronology and Hf Isotopes
}

\author{
Ziwen Jiang ${ }^{1}$, Jinglan Luo ${ }^{1, *}$, Xinshe Liu ${ }^{2,3}$, Xinyou $\mathrm{Hu}^{2,3}$, Shangwei Ma ${ }^{4}$, Yundong Hou ${ }^{2,3}$, \\ Liyong Fan ${ }^{2,3}$ and Yuhua $\mathrm{Hu}^{1}$ \\ 1 State Key Laboratory of Continental Dynamics, Department of Geology, Northwest University, \\ Xi'an 710069, China; jiangziwen0601@163.com (Z.J.); a13572804005@163.com (Y.H.) \\ 2 State Engineering Laboratory of Exploration and Development for Low Permeability Oil and Gas Fields, \\ Xi'an 710018, China; lxs_cq@petrochina.com.cn (X.L.); huxinyou_cq@petrochina.com.cn (X.H.); \\ hyd_cq@petrochina.com.cn (Y.H.); lyfan123_cq@petrochina.com.cn (L.F.) \\ 3 Research Institute of Petroleum Exploration and Development, PetroChina Changqing Oilfield Company, \\ Xi'an 710018, China \\ 4 Shaanxi Mineral Resources and Geological Survey, Xi'an 710068, China; mashangwei123@163.com \\ * Correspondence: jlluo@nwu.edu.cn
}

Received: 9 February 2020; Accepted: 13 March 2020; Published: 15 March 2020

\begin{abstract}
Carboniferous-Permian detrital zircons are recognized in the Upper Paleozoic of the whole Ordos Basin. Previous studies revealed that these Carboniferous-Permian zircons occurred in the Northern Ordos Basin mainly originated from the Yinshan Block. What has not been well documented until now is where this period's zircons in the Southern Ordos Basin came from, and very little discussion about their provenance. To identify the provenance of the detrital zircons dating from $\sim 350$ to $260 \mathrm{Ma}$, five sandstone samples from the Shan 1 Member of Shanxi Formation and eight sandstone samples from the He 8 Member of Shihezi Formation were analyzed for detrital zircon $\mathrm{U}-\mathrm{Pb}$ age dating and in situ Lu-Hf isotopic compositions. The results indicate that the two age clusters of 520-378 Ma and 350-260 Ma in the Southern Ordos Basin most likely derived from the North Qinling Orogenic Belt-North Qilian Orogenic Belt and the North Qinling Orogenic Belt, respectively. Furthermore, we propose that the zircons aging $~ 320-260 \mathrm{Ma}$ are representative of the important tectonothermal events occurred in the North Qinling Orogenic Belt during the Late Paleozoic.
\end{abstract}

Keywords: provenance; detrital zircon; LA-ICP-MS; U-Pb dating; Lu-Hf isotope; Upper Paleozoic; Ordos Basin

\section{Introduction}

The Ordos Basin, located in the southwest part of the North China Craton (Figure 1), is the second largest sedimentary basin in China [1] and is over 250,000 $\mathrm{km}^{2}$ in size [2]. Abundant oil and gas resources occur in the Upper Paleozoic clastic rocks of the basin.

The Carboniferous-Permian ( 350-260 Ma) detrital zircons are widely distributed in the Upper Paleozoic of the whole Ordos Basin, which are believed to be a derivation from the Yinshan Block in the Northern Ordos Basin [3]. At present, some studies have investigated the source of the Upper Paleozoic in the Southern Ordos Basin (SOB) [4-12]. Previous studies that used the methods of analyzing sandstone detrital component [4-7,9-11], sandstone composition [4-7,9-11], heavy mineral component $[4,5,7-9,11]$, whole rock geochemistry $[4,6]$, and the analyses of the paleocurrent $[4,5,8-11]$ and sedimentary facies $[4,7-9]$ in the SOB suggest that the source supplying directions of the Upper 
Paleozoic were from southwest to northeast, southeast to northwest and south to north, and the main source areas were the North Qinling Orogenic Belt (NQinOB) and North Qilian Orogenic Belt (NQiOB). However, the provenance of the $\sim 350-260$ Ma detrital zircons in the SOB was poorly defined.

Geologists have not paid enough attention to the $\sim 350-260 \mathrm{Ma}$ tectonothermal events due to the poor tectonothermal event records in the NQinOB and NQiOB, however, there are Carboniferous-Permian magmatic event records in the Yinshan Block. The detrital zircons from the Carboniferous-Triassic sandstone in the Liuyehe Basin (LYHB), which is an intermountain basin in the NQinOB [4,6,8] (Figure 1b), also present an age group of $\sim 350-260 \mathrm{Ma}[13,14]$. Gao et al. (2015) and Li et al. (2015) suggested that the provenance of the $\sim 350-260 \mathrm{Ma}$ zircons in the Liuyehe Basin was from the NQinOB $[13,14]$. It shows that dated 350-260 Ma tectonothermal events once occurred in the NQinOB. In the published literatures, there are few studies on the geochronology of the Upper Paleozoic in the SOB. Only Dai et al. (2016) studied the provenance of the Upper Paleozoic in the Southwestern Ordos Basin using zircon age distribution [12]. The studies by conventional provenance analysis methods show that the sources of the Upper Paleozoic in the SOB derived from the NQinOB and NQiOB. Therefore, there is no reliable evidence to determine whether the zircons of $350-260$ Ma were from the NQinOB, NQiOB or from the Yinshan Block.

The laser ablation-inductively coupled plasma-mass spectrometry (LA-ICP-MS) technique has been used in geological research for more than 30 years [15-23]. In the past decade, the mountain orogenesis and basin deposition coupling analyses based on the detrital zircon U-Pb dating was successfully used to determine precisely the provenance of sedimentary rocks, especially with in situ zircon Lu-Hf isotopic analyses [24-28]. In this study, the Shan 1 Member of Shanxi Formation (Fm.) and the He 8 Member of Shihezi Fm. in the SOB are selected as typical representatives, and the detrital zircon $\mathrm{U}-\mathrm{Pb}$ age dating and $\mathrm{Lu}-\mathrm{Hf}$ isotopic analysis are utilized to provide insight into the provenance of the Carboniferous-Permian detrital zircons in the SOB. It is further verified whether there are any 350-260 Ma tectonothermal events occurred in the NQinOB.

\section{Geological Background}

The Ordos Basin is surrounded by the Khondalite Belt and Yinshan Block (YB) to the north, the Helanshan-Liupanshan Thrust Belt to the west, the Qinling Orogenic Belt to the south, and the Trans-North China Orogen to the east [29] (Figure 1b). The Ordos Basin is a typical multicycle cratonic basin, which is covered by the Mesoproterozoic to Cenozoic sedimentary rocks on the Archean-Paleoproterozoic basement [1,2,29,30]. The study area is located in the south margin of the Ordos Basin (Figure 1a). In the Late Paleozoic, there were extension events, which led to a thick sequence of clastic rock deposits [31-34], including the Carboniferous Benxi Fm., the Permian Taiyuan Fm., Shanxi Fm., Shihezi Fm., and Shiqianfeng Fm. (Figure 1a).

The sediments of Benxi Fm. are mainly composed of sandstone-mudstone of littoral and neritic facies, limestone of tidal flat facies, and coal and carbonaceous mudstone of littoral swamp facies [35]. The Taiyuan Fm. is characterized by the interbedded mudstone, carbonaceous mudstone, limestone, coal seam and sandstone formed in deltaic plain facies and tidal flat facies [35]. Lithology of the Shanxi Fm. is mainly composed of dark-gray to gray-black mudstone, siltstone and fine-medium grained sandstone [35]. The Shanxi Fm. can be divided into two members of the Shan 1 Member and Shan 2 Member (Figure 1a). The layered sandstone, massive sandstone and coal seams are common in the Shan 2 Member. The Shan 1 Member is the upper part of Shanxi Fm. (Figure 1a) with rock assemblage including interbedded gray-black mudstone, coal seam, siltstone, and sandstone (Figure 2a). The Shihezi Fm. is a set of pebbly sandstones formed in the Middle Permian and can be divided into eight members (Figure 1a), of which, the He 8 Member is the lowest part with a thickness ranging from 40 to $70 \mathrm{~m}$. The bottom of the He 8 Member is named the Camel Neck Sandstone, which conformably overlayed on the Shanxi Formation (Figure 2a). The Camel Neck Sandstone is mainly composed of pebbly medium-coarse grained sandstone (Figure 2a,c). The upper part of the He 8 Member is characterized by the gravel-bearing medium-coarse grained sandstone, interbedded medium-coarse grained sandstone and fine-medium grained sandstone with lamellar mudstone 
(Figure 2b). Tabular cross bedding, parallel bedding, and fragments of plant fossils are very common in the He 8 Member (Figure 2d,e).
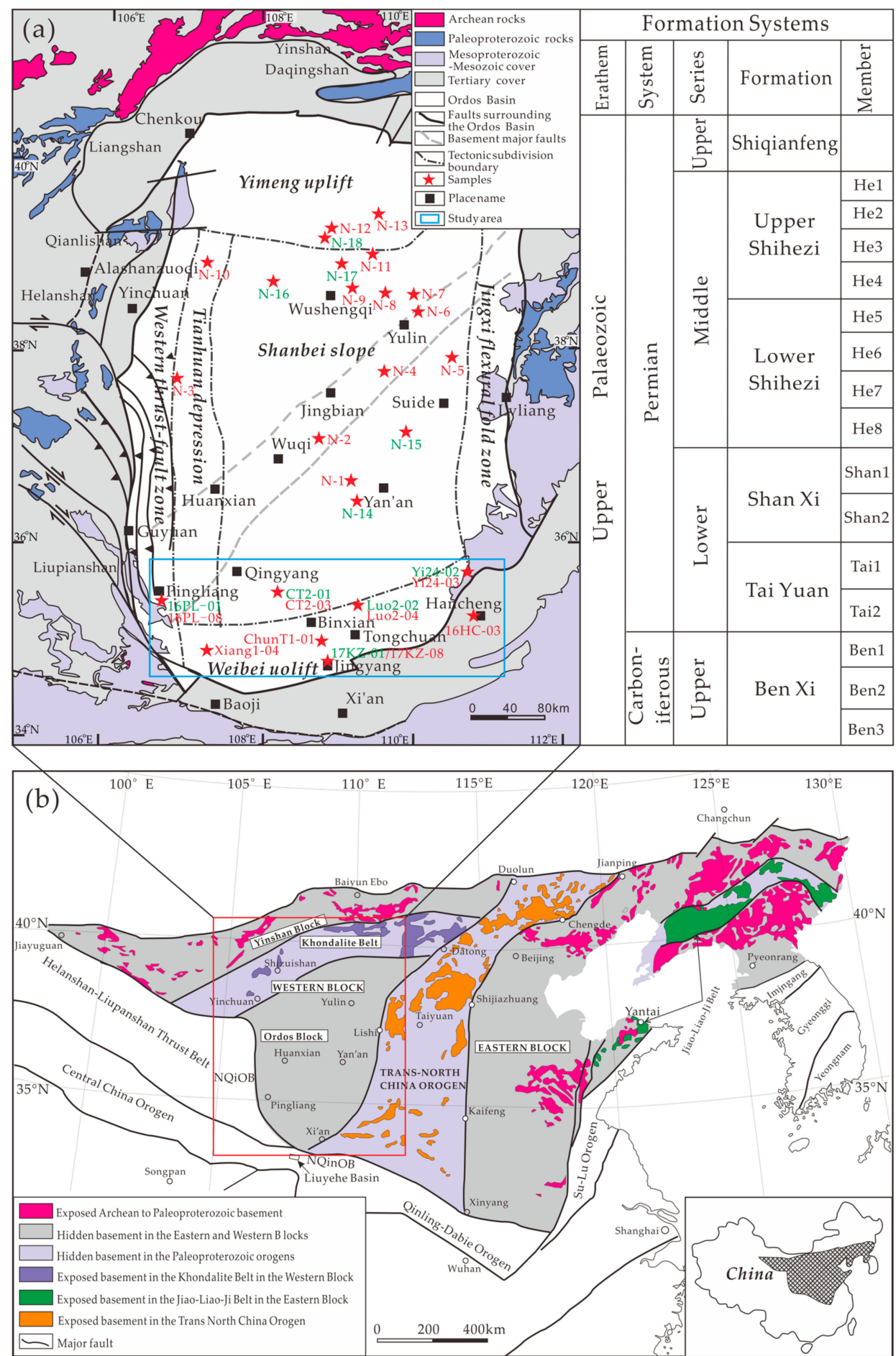

Figure 1. Schematic geological map showing the tectonic subdivision of the Ordos Basin (a), modified from [29]) and North China Craton (b), modified from [36], NQinOB: North Qinling Orogenic Belt, NQiOB: North Qilian Orogenic Belt), and the Ordos Basin with the Upper Paleozoic formation systems (modified from [12]). 


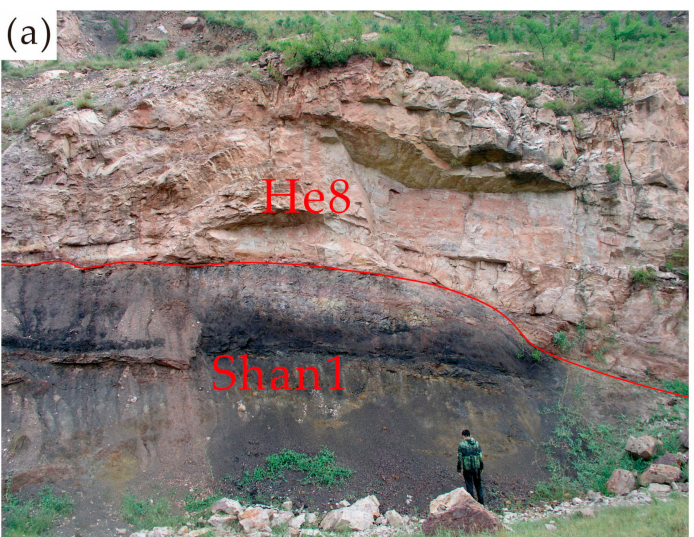

(c)

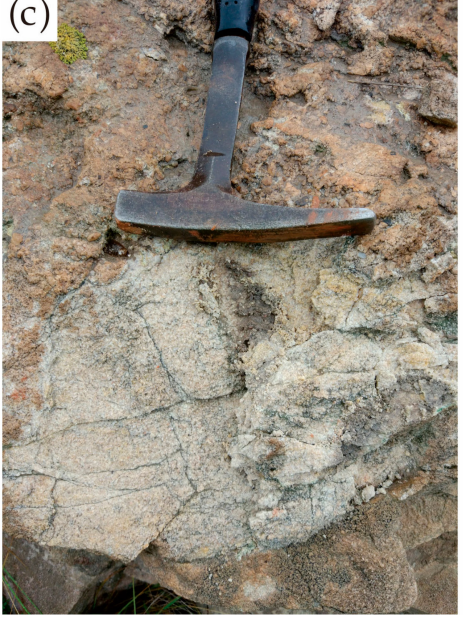

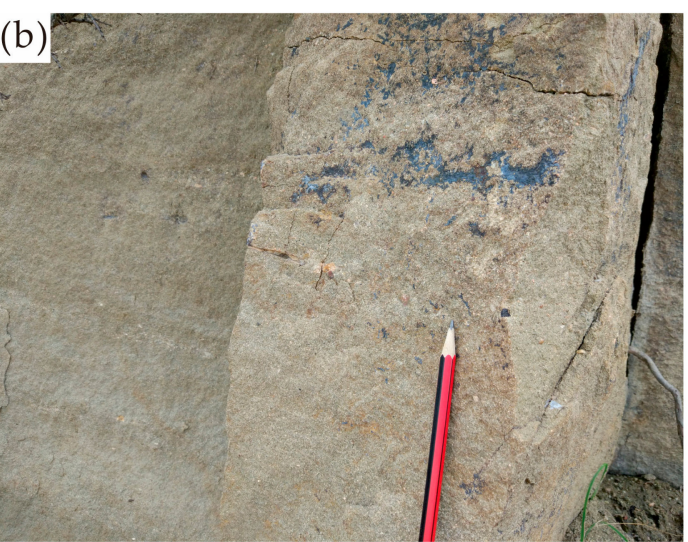
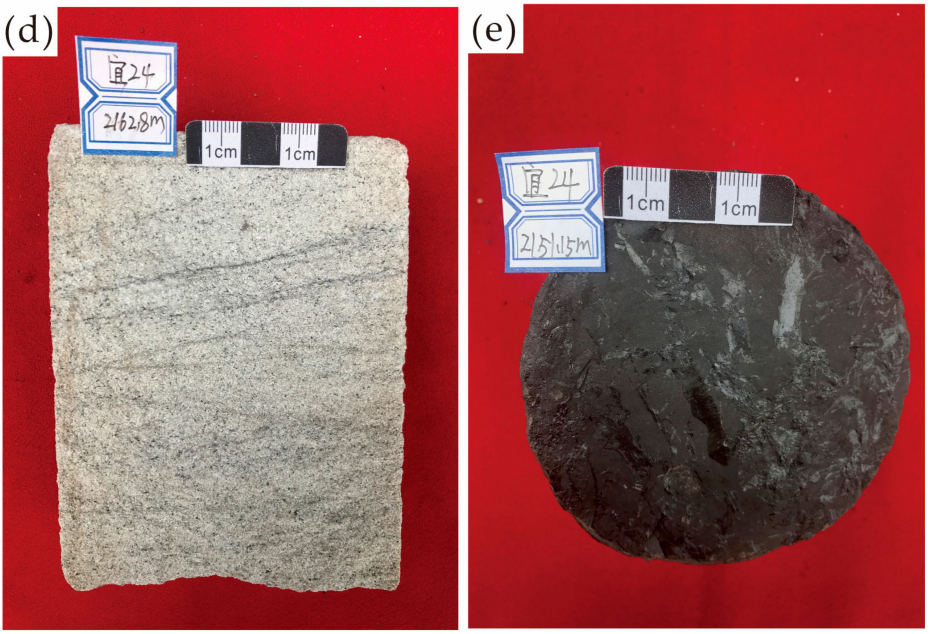

Figure 2. Photographs of the field outcrops and drilling cores in the study area. (a) the boundary between the Shan 1 and He 8 Member of the Kouzhen outcrop; (b) pebbly medium-coarse grained sandstone of the Hancheng outcrop; (c) pebbly coarse grained sandstone of the Kouzhen outcrop; (d) tabuler cross bedding in the medium grained sandstone from the drilling cores in Well Yi24; (e) the fragments of plant fossils in the grey-black mudstone from the drilling cores in Well Yi24.

\section{Sampling and Methodology}

\subsection{Sampling Information}

Five sandstone samples from the Shan 1 Member and eight sandstone samples from the He 8 Member were collected from five boreholes and three field outcrops (Kouzhen, Xuefengchuan and Pingliang outcrop) in the SOB for the detrital zircon $\mathrm{U}-\mathrm{Pb}$ chronologic and Lu-Hf isotopic analyses (Table 1 and Figure 1a). We also collected zircon U-Pb age data of the 18 samples in the Northern Ordos Basin, and the samples of N14-N18 and N1-N13 are from the Shan 1 Member and He 8 Member, respectively. The sampling locations are shown in Figure 1a. Of these study samples, the research of petrographic characteristics shows that most of the quartz in 13 sandstone samples are sub-angular or sub-rounded (Figure 3). The quartz overgrowth is common (Figure $3 a, b, f)$. Feldspars $(\sim 3 \%-7 \%)$ are found in the samples of ChunT1-01 and 16HC-03. Most of the feldspars are sub-angular and corroded (Figure 3c,e). In addition, lithic fragments are very common in samples, especially in the samples of Luo2-04 and 16HC-03 (Figure 3), and most of them are metamorphic and volcanic fragments with some clay mineral and carbonate cement. Detailed information on the samples is presented in Table 1. 

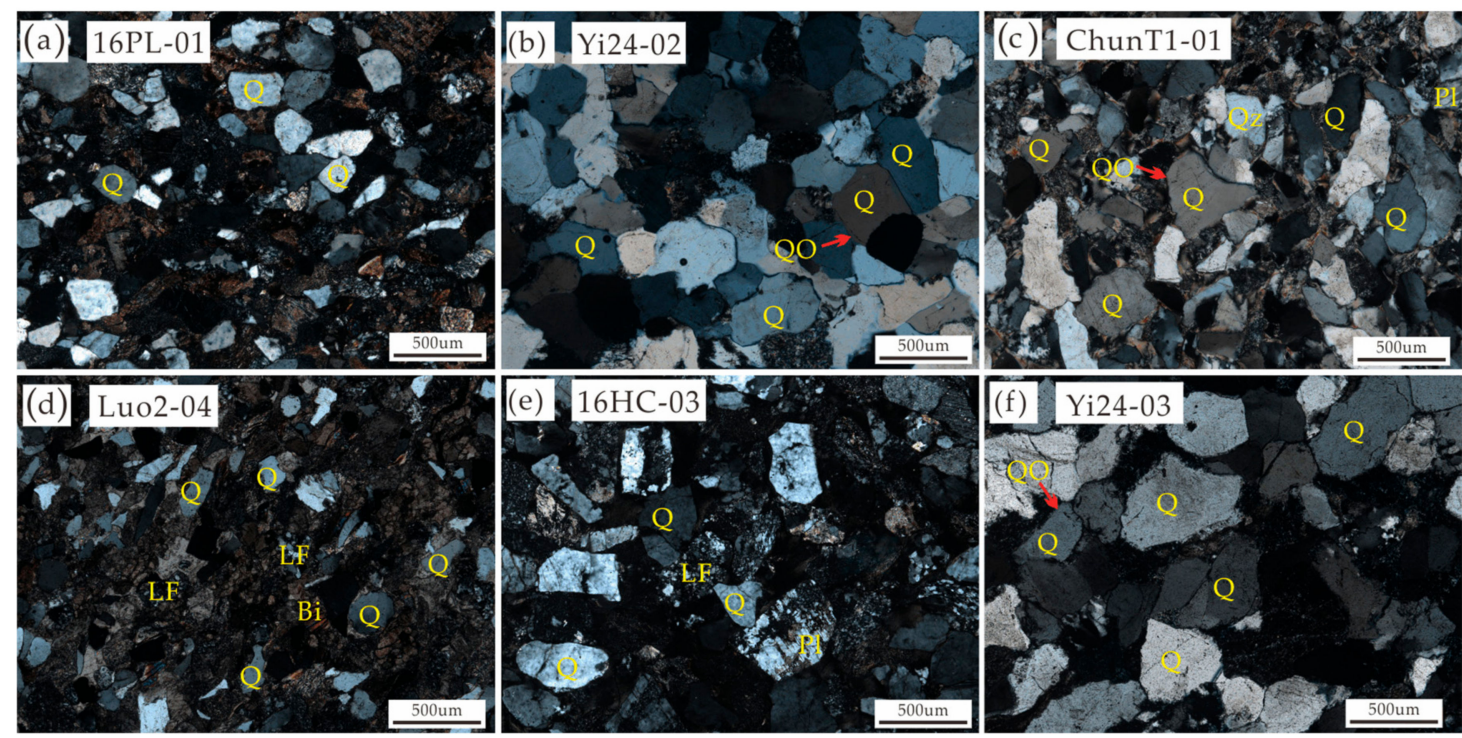

Figure 3. Microphotos of the sandstone samples from the SOB. All are shown under cross-polarized light. Q: quartz, Pl: plagioclase, Bi: biotite, LF: lithic fragment, QO: quartz overgrowth.

Table 1. Summarized samples description.

\begin{tabular}{|c|c|c|c|c|c|c|c|}
\hline Well/Section & Stratum & Sample & Lithology & $\mathrm{n}^{1} / \mathrm{n}^{2}$ & $n^{3} / n^{4}$ & $n^{5} / n^{6}$ & Brief Description \\
\hline \multirow[t]{2}{*}{ Pingliang } & Shan 1 & 16PL-01 & Quartz sandstone & $81 / 102$ & $12 / 17$ & $7 / 47$ & $\begin{array}{l}\text { Gray, fine-medium } \\
\text { grained }\end{array}$ \\
\hline & He 8 & 16PL-08 & Quartz sandstone & $97 / 100$ & $12 / 12$ & $11 / 61$ & $\begin{array}{c}\text { Off white, } \\
\text { medium-coarse grained }\end{array}$ \\
\hline \multirow[t]{2}{*}{ ChengTan 2} & Shan 1 & CT2-01 & Quartz sandstone & $90 / 102$ & $9 / 12$ & $7 / 38$ & $\begin{array}{l}\text { Gray, medium-coarse } \\
\text { grained }\end{array}$ \\
\hline & He 8 & CT2-03 & Quartz sandstone & $85 / 102$ & $14 / 20$ & $7 / 26$ & $\begin{array}{c}\text { Off white, } \\
\text { medium-coarse grained }\end{array}$ \\
\hline \multirow[t]{2}{*}{ Kouzhen } & Shan 1 & 17KZ-01 & Quartz sandstone & $65 / 102$ & $7 / 9$ & $7 / 49$ & $\begin{array}{l}\text { Yellow-gray, medium } \\
\text { grained }\end{array}$ \\
\hline & He 8 & $17 \mathrm{KZ}-08$ & Quartz sandstone & $56 / 102$ & $3 / 15$ & $3 / 42$ & $\begin{array}{c}\text { Off white, } \\
\text { medium-coarse grained }\end{array}$ \\
\hline \multirow{2}{*}{ Luo 2} & Shan 1 & Luo2-02 & Quartz sandstone & $90 / 102$ & $14 / 22$ & $10 / 34$ & \multirow{2}{*}{$\begin{array}{l}\text { Gray, medium grained } \\
\text { Gray, fine-medium } \\
\text { grained }\end{array}$} \\
\hline & He 8 & Luo2-04 & Lithic sandstone & $80 / 101$ & $14 / 21$ & $10 / 30$ & \\
\hline \multirow{2}{*}{ Yi 24} & Shan 1 & Yi24-02 & Quartz sandstone & $78 / 102$ & $16 / 26$ & $14 / 40$ & \multirow{2}{*}{$\begin{array}{c}\text { Off white, } \\
\text { medium-coarse grained } \\
\text { Gray, fine-medium } \\
\text { grained }\end{array}$} \\
\hline & He 8 & Yi24-03 & Quartz sandstone & $81 / 102$ & $12 / 15$ & $10 / 32$ & \\
\hline Xiang 1 & He 8 & Xiang1-04 & Quartz sandstone & $74 / 102$ & $14 / 27$ & $10 / 34$ & \multirow{3}{*}{$\begin{array}{c}\text { Off white, } \\
\text { medium-coarse grained } \\
\text { Off white, } \\
\text { medium-coarse grained } \\
\text { Yellow-gray, } \\
\text { medium-coarse grained }\end{array}$} \\
\hline ChunTan 1 & He 8 & ChunT1-01 & Quartz sandstone & $83 / 102$ & $35 / 47$ & $14 / 35$ & \\
\hline Hancheng & He 8 & 16HC-03 & Lithic sandstone & $89 / 101$ & $10 / 16$ & $9 / 47$ & \\
\hline
\end{tabular}

$\mathrm{n}^{1}$ : number of zircon U-Pb ages with in $90 \%-110 \%$ concordance. $\mathrm{n}^{2}$ : number of all zircon U-Pb dating in sample. $\mathrm{n}^{3}$ : number of the 550-260 Ma zircon U-Pb ages with in 90\%-110\% concordance. $\mathrm{n}^{4}$ : number of the 550-260 Ma zircons $\mathrm{U}-\mathrm{Pb}$ dating in sample. $\mathrm{n}^{5}$ : number of the 550-260 Ma zircon Lu-Hf isotopic analysis. $\mathrm{n}^{6}$ : number of all Lu-Hf isotopic analysis in sample.

\subsection{Zircon Separation and CL Imaging}

Zircon minerals were separated by traditional heavy liquid and magnetic techniques [37], and handpicked using a binocular microscope. More than 200 zircon grains were randomly selected and fixed in epoxy resin in a $1 \mathrm{~cm}$ diameter mount, and then polished until the interior surfaces of all zircons were exposed. All zircons were documented in the optical photomicrographs under the transmitted, reflected light and cathodoluminescence (CL) imaging to uncover their internal structures [37]. The CL images were taken at the State Key Laboratory of Continental Dynamics, 
Northwest University, Xi'an, China. A detailed description of using instruments was described by Wang et al. [38].

\subsection{LA-ICP-MS Zircon Dating}

The U-Pb isotopic ratios of zircons were measured in situ using a GeoLasPro 193 UV laser ablation system (Lambda Physik AG, Göttingen, Germany) coupled with a 7500a ICP-MS (Agilent Technologies Inc., Santa Clara, CA, USA) at the State Key Laboratory of Continental Dynamics, Northwest University, $\mathrm{Xi}^{\prime}$ an, China. The laser beam size and frequency were $32 \mu \mathrm{m}$ and $6 \mathrm{~Hz}$, respectively. Three international standard samples of zircon NIST SRM 610, 91500, GJ-1 were tested for every twelve sample analyses, and one standard sample 91500 was tested after the sixth sample of those 12 sample analyses. In order to calculate zircon ages, the zircon 91500 was adopted as an external standard. The detailed instrumental settings and analytical procedures were described by Yuan et al. [39], Diwu et al. [40] and Thomas [41]. The $\mathrm{U}$, Th and $\mathrm{Pb}$ concentrations as well as ${ }^{207} \mathrm{~Pb} /{ }^{206} \mathrm{~Pb},{ }^{206} \mathrm{~Pb} /{ }^{238} \mathrm{U},{ }^{207} \mathrm{~Pb} /{ }^{235} \mathrm{U}$ and ${ }^{208} \mathrm{~Pb} /{ }^{232} \mathrm{Th}$ ratios were computed by GLITTER 4.0 software (Macquarie University, Sydney, Australia). Their ages were calculated by Isoplot/Ex v. 3.0 [42]. For the element content analysis, the artificial synthetic silicate glass NIST SRM 610 of the American National Standard Substance Bureau, as an external standard, was used to calibrate $\mathrm{U}$, Th and $\mathrm{Pb}$ concentration, while ${ }^{29} \mathrm{Si}$ was adopted as the internal standard element. All analytical results are shown in Supplementary Table S1.

\subsection{Zircon Lu-Hf Isotopic Analysis}

In situ zircon Lu-Hf isotopic analyses were carried out on a Nu Plasma II MC-ICP-MS (Nu Instruments Ltd., Wrexham, UK) connected to a RESOLution M-50 193 nm laser system at the State Key Laboratory of Continental Dynamics, Northwest University (Xi'an, China). The spot size was $44 \mu \mathrm{m}$. Lu-Hf isotopic measurements were taken at the same spots or in the same age domains of zircon grains with concordant $\mathrm{U}-\mathrm{Pb}$ age (discordance $<10 \%$ ). The international standard zircon 91500 was used as an external correction. The running state of the instrument was described by Bao et al. (2017) [43], and detailed information of the analysis strategy and data deduction is stated in the published literature [44]. $\mathrm{A}^{176} \mathrm{Hf} /{ }^{177} \mathrm{Hf}$ ratio of 0.282772 and ${ }^{176} \mathrm{Lu} /{ }^{177} \mathrm{Hf}$ of 0.0332 [45] of the chondritic were used to calculate $\varepsilon_{\mathrm{Hf}}(\mathrm{t})$, and single-stage Hf model ages $\left(\mathrm{T}_{\mathrm{DM} 1}\right)$ and two-stage Hf model ages $\left(\mathrm{T}_{\mathrm{DM} 2}\right)$ were calculated by the depleted mantle with ${ }^{176} \mathrm{Hf} /{ }^{177} \mathrm{Hf}$ value of 0.28325 [46], ${ }^{176} \mathrm{Lu} /{ }^{177} \mathrm{Hf}$ of 0.0384 [46], ${ }^{176} \mathrm{Hf} /{ }^{177} \mathrm{Hf}$ of 0.28325 [46] and $\lambda$ of $1.867 \times 10^{-11}$ year $^{-1}[47]$. The $\mathrm{f}_{\mathrm{Lu} / \mathrm{Hf}}$ of the upper crust is -0.72 [48], and the $\mathrm{f}_{\mathrm{Lu} / \mathrm{Hf}}$ of the depleted mantle is 0.16 [46]. Calculation formulas of $\varepsilon_{\mathrm{Hf}}(\mathrm{t}), \mathrm{T}_{\mathrm{DM} 1}, \mathrm{~T}_{\mathrm{DM} 2}$ and $\mathrm{f}_{\mathrm{Lu} / \mathrm{Hf}}$ of samples according to Wu et al. (2007) were used [49]. The results are presented in Supplementary Table S2.

\section{Results}

\subsection{U-Pb Ages}

In order to study the potential relationship between zircon age and grain size, the grain size and shape parameters of each dated zircon were measured and used to calculate the equivalent spherical diameter (ESD) [50]. The ESD is the cube root of the length values of the three axes of zircon grains [50,51]. Figure 4 shows that the distribution of ages is independent from ESD i.e., the dated zircon ages can be regarded as representatives of whole rocks [50]. 


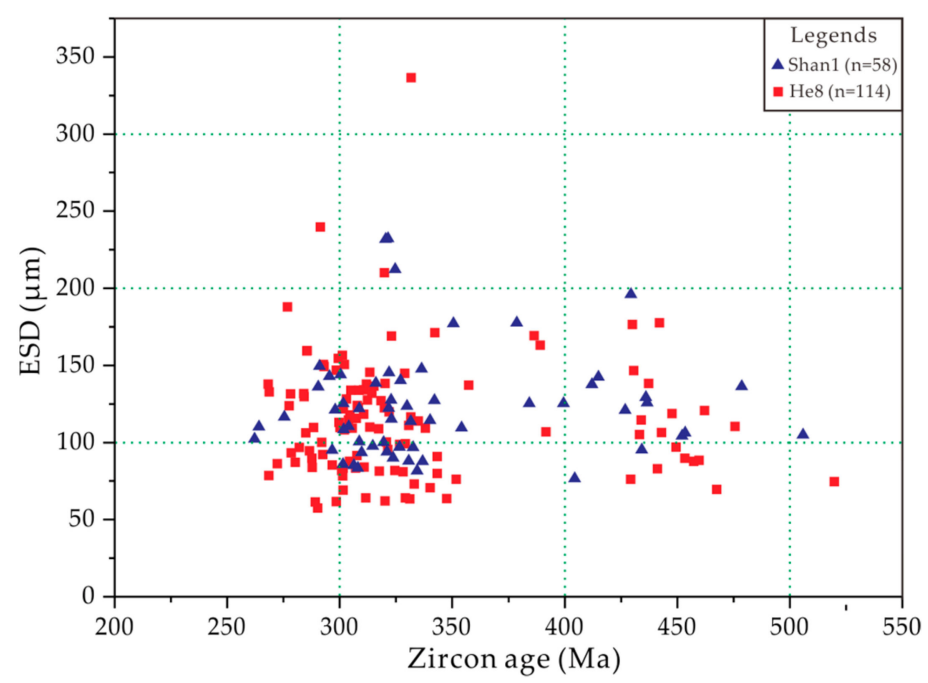

Figure 4. Equivalent spherical diameter (ESD) of zircon grains vs detrital zircon ages in samples. The distribution of ages is independent from grain-size.

A total of 510 and 812 detrital zircons in the Shan 1 and He 8 Member were analyzed, and 404 and 645 grains' ages were concordant (discordance $<10 \%$ ), respectively. Of these, 85 (Shan 1) and 173 (He 8) grains yielded ages of 520-262 Ma (Table S1), and 58 and 114 spots gave concordant ages, respectively. The analytical results of 520-260 Ma are shown in the Supplementary Table S1. The concordant ages of the Shan 1 Member samples range from 509.9 Ma to $262.2 \mathrm{Ma}$, with peaks at $432 \mathrm{Ma}, 400 \mathrm{Ma}, 325 \mathrm{Ma}$ and $302 \mathrm{Ma}$. In contrast, those in the He 8 Member range from 519.7 Ma to 268.2 Ma, with peaks at $439 \mathrm{Ma}, 323 \mathrm{Ma}, 305 \mathrm{Ma}$ and $286 \mathrm{Ma}$. The majority of the detrital zircons lie on the concordant curve (Figure 5). Most of the zircons are subhedral to euhedral, displaying a short to long prismatic, and sub-rounded to rounded shapes, with a length of 80-250 $\mu \mathrm{m}$, which are similar to the magmatic zircon with the length of between 20 and $250 \mu \mathrm{m}$ [52,53], and a width of 50-230 $\mu \mathrm{m}$ and length/width ratios of 1:1-3.5:1 (Figure 6). Some zircons exhibit dark or blurry oscillatory zoning (Figure 6) with $\mathrm{Th} / \mathrm{U}$ ratios $>0.4$, suggesting a magmatic origin [52,54-57]. Two grains display fan zoning structures (Figure $6 \mathrm{~m}$ ), which may indicate a metamorphic origin [52,54-56] and yielded ages of $301.1 \pm 2.6 \mathrm{Ma}$ and $284.2 \pm 3.3 \mathrm{Ma}$. Generally, the Th/U ratio of igneous zircon is $>0.4$ and metamorphic zircon is $<0.1[53,58,59]$, which can be used to distinguish the origin of the zircons. Most of the analyzed zircons have the Th/U ratios $>0.4$, and 21 grains (9 in Shan 1 and 12 in He 8) with the ratios of 0.1-0.4, and only three grains less than 0.1 (one in Shan 1 and two in He 8) (Table S1 and Figure 7), indicating main magmatic origin and a few metamorphic origin. Of which, three zircons with the Th/U ratios $<0.1$ were aged at $404.4 \pm 2.6 \mathrm{Ma}$ (Shan 1 Member), $443.0 \pm 2.6 \mathrm{Ma}$, and $391.6 \pm 2.3 \mathrm{Ma}$ (He 8 Member), indicating a metamorphic origin.

The U-Pb age data of 18 sandstones were collected in the Northern Ordos Basin, and ages' peak at $438 \mathrm{Ma}, 408 \mathrm{Ma}, 372 \mathrm{Ma}, 337 \mathrm{Ma}, 321 \mathrm{Ma}$ and $302 \mathrm{Ma}$ (Figure 8e). The samples of N14-N18 were from the Shan 1 Member, with peaks at $411 \mathrm{Ma}, 378 \mathrm{Ma}, 318 \mathrm{Ma}$ and $304 \mathrm{Ma}$ (Figure 8c), and the samples of N1-N13 from the He 8 Member peaking at 438 Ma, 405 Ma, 335 Ma, 320 Ma and 304 Ma (Figure 8d).

\subsection{Lu-Hf Isotopic Compositions}

In situ Lu-Hf isotopic compositions were measured a total number of 45 grains from the Shan 1 Member and 74 grains from the He 8 Member. As shown in Table S2 and Figure 9, the $\varepsilon_{\mathrm{Hf}}(\mathrm{t})$ values of the samples from the Shan 1 Member yielded a wide range from -20.84 to 11.37 , with the $\mathrm{T}_{\mathrm{DM} 2}$ of $679-2178 \mathrm{Ma}$. Among these, 41 zircons yielded negative $\varepsilon_{\mathrm{Hf}}(\mathrm{t})$ values from -20.84 to -1.88 , with the $\mathrm{T}_{\mathrm{DM} 2}$ of 1041-2178 Ma and the remaining four grains have positive $\varepsilon_{\mathrm{Hf}}(\mathrm{t})$ values from 0.22 to 11.37 , with the $\mathrm{T}_{\mathrm{DM} 2}$ of $679-1209 \mathrm{Ma}$ (Table S2 and Figure 9). 


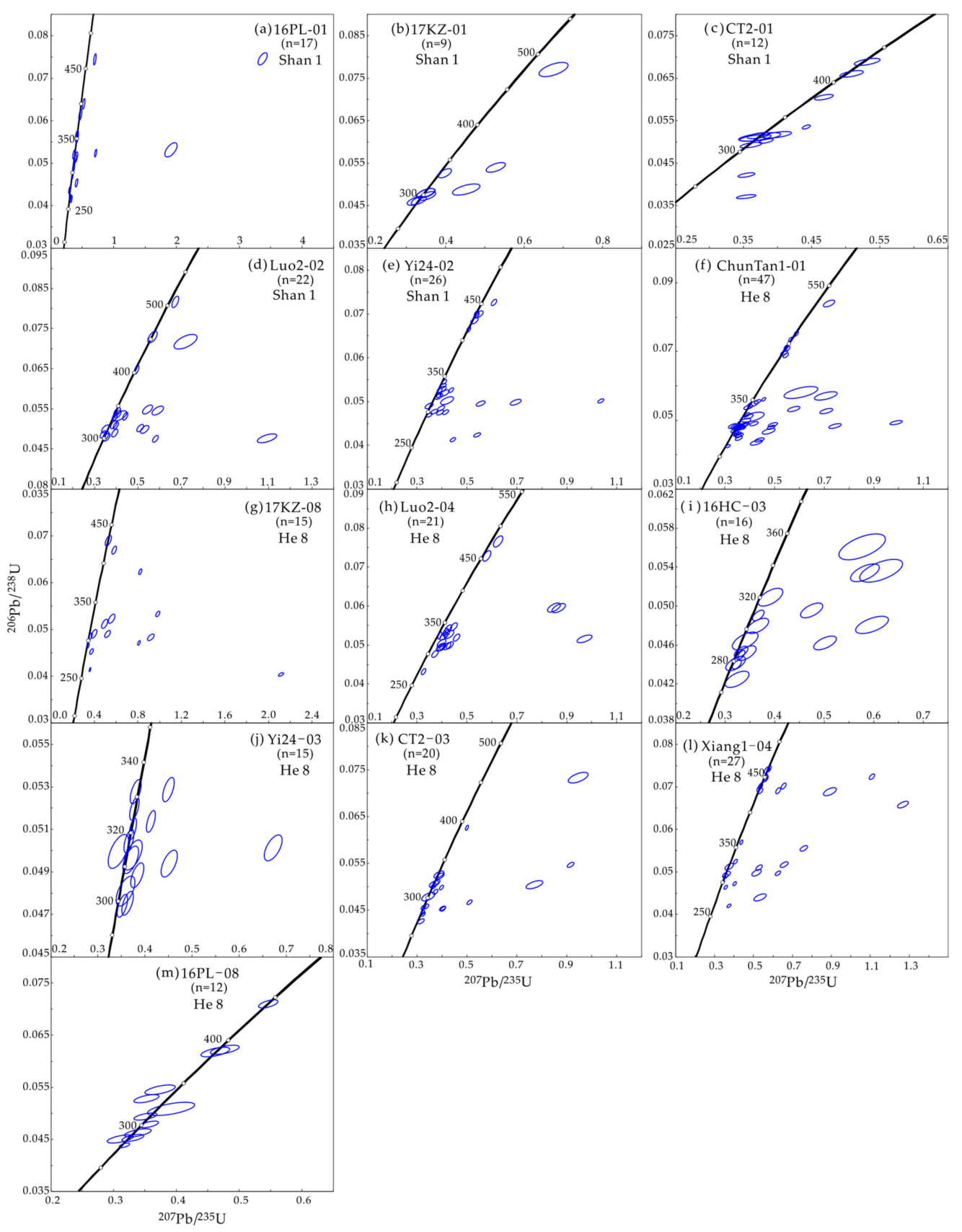

Figure 5. U-Pb concordia diagrams of 520-260 Ma detrital zircons. Errors are quoted at the $1 \sigma$ level. 


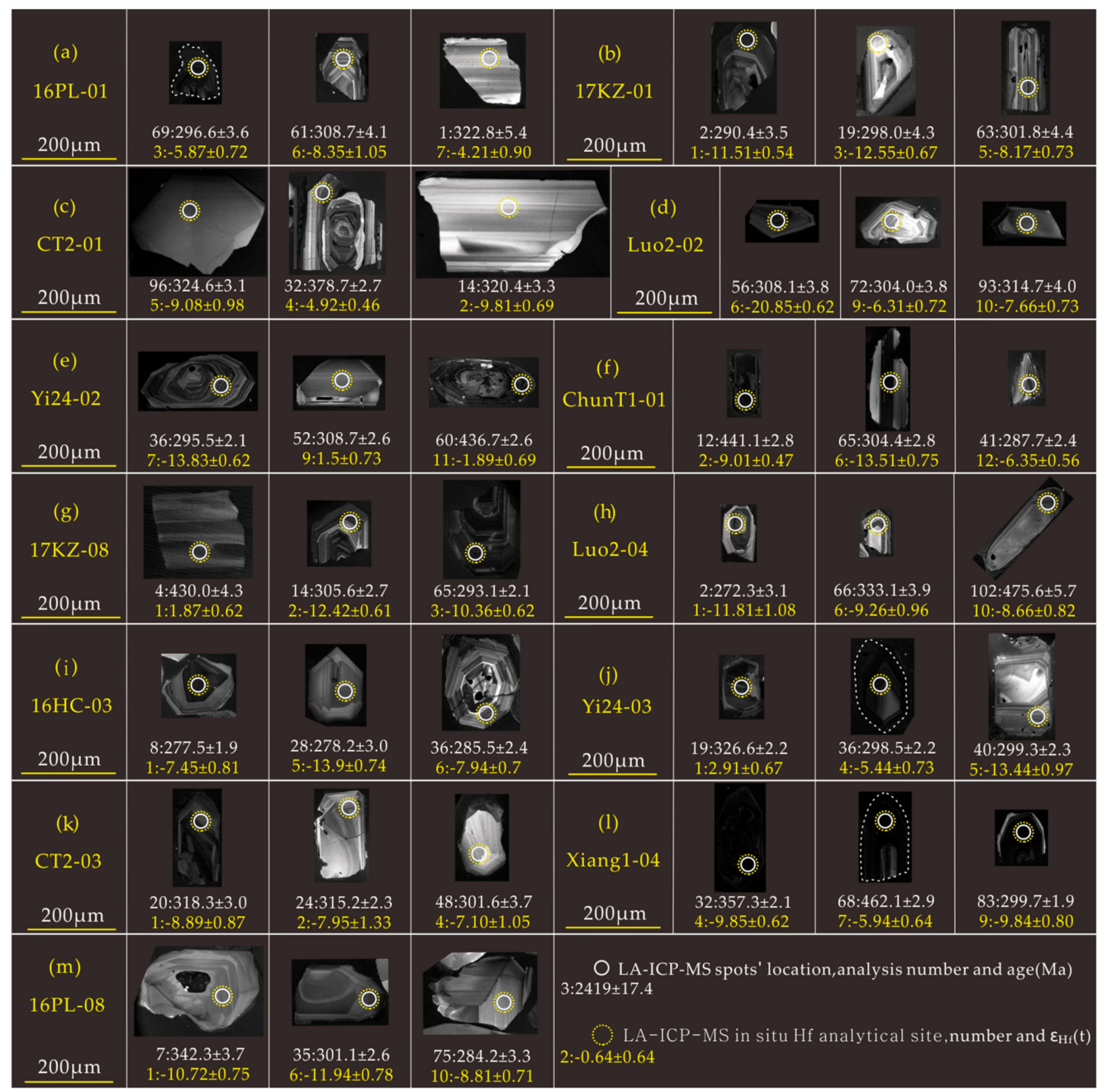

Figure 6. Representative cathodoluminescence (CL) images of the zircons from all samples.

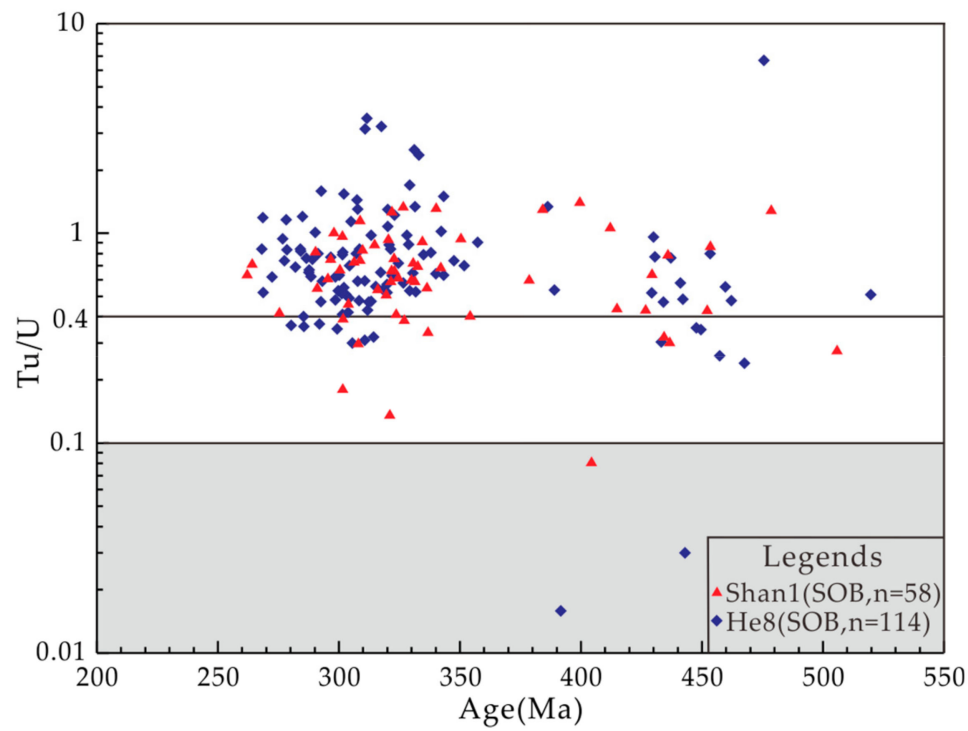

Figure 7. $\mathrm{U}-\mathrm{Pb}$ age vs. $\mathrm{Th} / \mathrm{U}$ ratio diagram. The shaded area denotes values for typical metamorphic zircons with $\mathrm{Th} / \mathrm{U}<0.1$. 

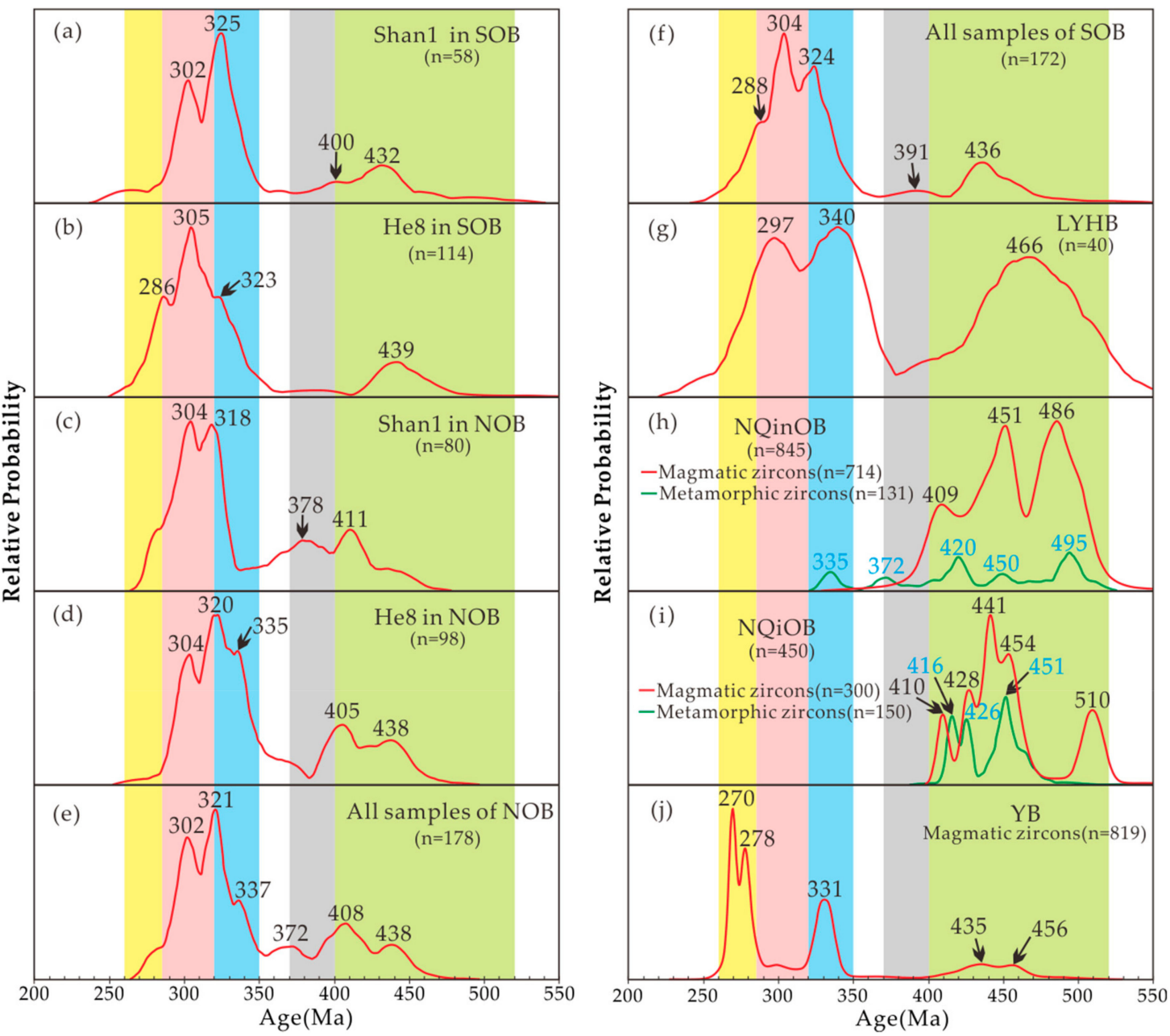

Figure 8. Contrasting relative probability plots of zircon $\mathrm{U}-\mathrm{Pb}$ ages. Only those ages with a discordance of less than $10 \%$ are used. The yellow, pink, blue, gray and green bars show the age groups of 285-260 Ma, 320-285 Ma, 350-320 Ma, 400-370 Ma and 520-400 Ma, respectively. Data sources: (h) the magmatic ages of the North Qinling Orogenic Belt (NQinOB) are from [60-71], and the metamorphic ages of the NQinOB from $[62,65,68,72-93]$; (i) the magmatic ages of the North Qilian Orogenic Belt (NQiOB) are from [94-110], and the metamorphic ages of the NQiOB from $[94,95,99,111-114]$; (j) the magmatic ages of the Yinshan Block (YB) are from [115-132]; (c)-(e) the detrital zircon ages of the Northern Ordos Basin (NOB) are from $[3,133,134]$; $(\mathrm{g})$ the detrital zircon ages of the Liuyehe Basin (LYHB) are from $[13,14]$, and the detrital zircon ages shown in Figure $8 \mathbf{a}, \mathbf{b}$ and $\mathbf{f}$ from this study. The relative probability curves were drawn on the DensityPlotter program (version 8.5 ) by using the model of Kernel Density Estimation (KDE) [135].

In the He 8 Member zircons, 68 analytical data yielded negative $\varepsilon_{\mathrm{Hf}}(\mathrm{t})$ values from -16.6 to -0.78 , with the $\mathrm{T}_{\mathrm{DM} 2}$ of 1164-1948 Ma (Table S2 and Figure 9). The remaining six grains have positive $\varepsilon_{\mathrm{Hf}}(\mathrm{t})$ values from 1.28 to 5.18 , with the $\mathrm{T}_{\mathrm{DM} 2}$ of $859-1125 \mathrm{Ma}$.

\section{Major Tectonothermal Events Analyses of Adjacent Regions}

The 520-260 Ma tectonothermal events occurred in the Yinshan Block (YB), North Qinling Orogenic Belt (NQinOB), and North Qilian Orogenic Belt (NQiOB) around the Ordos Basin (Figure 1b). Many zircon $\mathrm{U}-\mathrm{Pb}$ geochronology have been conducted over the past decades, and a great number of available ages have been obtained from these adjacent regions, providing us with a relatively well constrained framework for the provenance interpretation and correlation for the SOB. 

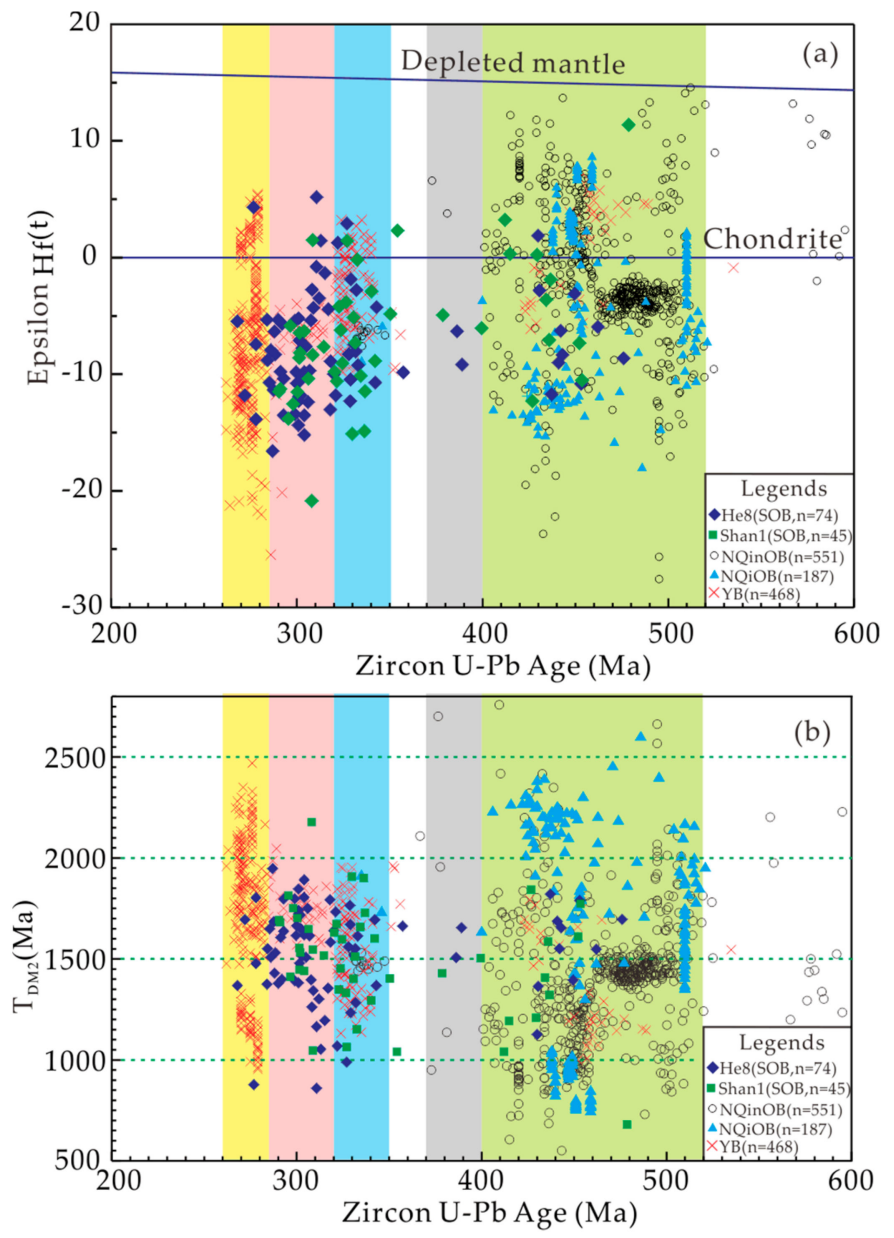

Figure 9. $\varepsilon_{\mathrm{Hf}}(\mathrm{t})$ values vs. U-Pb ages $(\mathbf{a})$ and $\mathrm{T}_{\mathrm{DM} 2}$ values vs. U-Pb ages $(\mathbf{b})$. The yellow, pink, blue, gray and green bars show the age groups of 285-260 Ma, 320-285 Ma, 350-320 Ma, 400-370 Ma and 520-400 Ma, respectively. The Hf isotope evolution line for Depleted Mantle follows [46]. The Lu-Hf isotopic compositions of the North Qinling Orogenic Belt (NQinOB) are from [60,61,64-67], the North Qilian Orogenic Belt (NQiOB) from [94-96,136], and the Yinshan Block (YB) from [115-124].

\subsection{North Qinling Orogenic Belt (NQinOB)}

Based on the previous detrital zircon U-Pb geochronology results of the NQinOB, three magmatic event age peaks at $486 \mathrm{Ma}, 451 \mathrm{Ma}$ and $409 \mathrm{Ma}$ can be recognized [60-71] (Figure 8h). They genetically related to the $\sim 500$ Ma deep continental-subduction, $\sim 450$ Ma crustal thickening and uplifting due to continent-continent collision, and subsequent crustal uplifting in $~ 420-400 \mathrm{Ma}$, respectively [60]. These zircons have $\varepsilon_{\mathrm{Hf}}(\mathrm{t})$ values from -27.6 to 14.6 (average -2.1 , Figure $9 \mathrm{a}$ ) and the $\mathrm{T}_{\mathrm{DM} 2}$ of 551-2759 Ma (average $1398 \mathrm{Ma}$, most of $\mathrm{T}_{\mathrm{DM} 2}$ between $0.8-2.0 \mathrm{Ga}$ ), suggesting the main reworking of Paleo-Neoproterozoic crust [60] (Figure 9b). Moreover, the 517-324 Ma metamorphic ages (peaks at $495 \mathrm{Ma}, 450 \mathrm{Ma}, 420 \mathrm{Ma}, 372 \mathrm{Ma}$ and $335 \mathrm{Ma}$ ) have also been reported (Figure 8h). The NQinOB experienced metamorphism at $\sim 500 \mathrm{Ma}$, and then overprinted medium-pressure granulite facies metamorphism at $\sim 450 \mathrm{Ma}$, and amphibolite facies at $\sim 420 \mathrm{Ma}$ during the Early Paleozoic $[59,60]$. These magmatic and metamorphic events suggest that the NQinOB underwent a multi-stage tectonic evolution of accretion and collision in the Paleozoic period $[34,137,138]$.

\subsection{North Qilian Orogenic Belt (NQiOB)}

In contrast to the NQinOB, there are some magmatic events with peaks at $510 \mathrm{Ma}, 454 \mathrm{Ma}, 441 \mathrm{Ma}$, $428 \mathrm{Ma}$ and $410 \mathrm{Ma}$ [94-110], and metamorphic events with peaks at $453 \mathrm{Ma}, 426 \mathrm{Ma}$ and $416 \mathrm{Ma}$ in the NQiOB $[94,95,99,111-114]$ (Figure 8i). Of all magmatic and metamorphic events ages, the zircons of the 
Paleozoic ages have variable $\varepsilon_{\mathrm{Hf}}(\mathrm{t})$ values from -18.1 to 8.6 (average -3.3 , most of $\varepsilon_{\mathrm{Hf}}(\mathrm{t})<0$, Figure $9 \mathrm{a}$ ) and the $\mathrm{T}_{\mathrm{DM} 2}$ of 742-2597 Ma (average $1559 \mathrm{Ma}$, most of $\mathrm{T}_{\mathrm{DM} 2}$ between $0.8-2.4 \mathrm{Ga}$ ), indicating a juvenile crust generation and reworking of Paleo-Neoproterozoic crust materials. Besides, the metamorphisms aged at $\sim 500-400 \mathrm{Ma}$ are widely found in the NQiOB and are regarded as representing the earliest oceanic subduction and later continental subduction [139].

\subsection{Yinshan Block (YB)}

The Yinshan Block is a micro-continental block that is closely adjacent to the north of the Khondalite Belt (Figure 1b) [140]. The Paleozoic magmatic events widely occurred during 350-260 Ma and 480-400 Ma (Figure 8j) [141-143]. The magmatism was recorded by a variety of zircon $\varepsilon_{\mathrm{Hf}}(\mathrm{t})$ values from -25.5 to 6.8 (average -5.2 , most of $\varepsilon_{\mathrm{Hf}}(\mathrm{t})<0$ ) and the $\mathrm{T}_{\mathrm{DM} 2}$ of 954-2470 Ma (average $1624 \mathrm{Ma}$, most of $\mathrm{T}_{\mathrm{DM} 2}$ between 1.0-2.3 Ga), indicating an arc magmatism related to oceanic subduction.

\section{Discussion}

\subsection{The provenance of 520-378 Ma Zircons.}

The 520-378 Ma zircon ages of all samples in the study area display two peaks at $\sim 440-430$ Ma and 400-390 Ma (Figure 8f). The 15 (Shan 1 Member) and 21 (He 8 Member) detrital zircon grains of the 520-378 Ma concordant ages were detected except for the samples of 16HC-03 and Yi24-03, accounting for $2.2 \%$ and $3.3 \%$ of the total, respectively. Most of the zircons have the $\mathrm{Th} / \mathrm{U}$ ratios $>0.4$, eight grains with ratios of $0.1-0.4$ and three grains with ratios $<0.1$ (Table S1 and Figure 7), indicating main magmatic origin and with minor metamorphic origin. Twelve zircons' Lu-Hf isotopic compositions in the Shan 1 Member samples were analyzed which yielded the $\mathrm{T}_{\mathrm{DM} 2}$ of $679-1843 \mathrm{Ma}$, and most of the $\mathrm{T}_{\mathrm{DM} 2}$ were from $1.2 \mathrm{Ga}$ to $1.85 \mathrm{Ga}$. Of these, eight zircons yielded negative $\varepsilon_{\mathrm{Hf}}(\mathrm{t})$ values from -12.32 to -1.88 (average -6.71 ), with the $\mathrm{T}_{\mathrm{DM} 2}$ of $1322-1843 \mathrm{Ma}$ (Table $\mathrm{S} 2$ and Figure 9 ). The other four grains provided positive $\varepsilon_{\mathrm{Hf}}(\mathrm{t})$ values of $0.22-11.37$, with the $\mathrm{T}_{\mathrm{DM} 2}$ of $679-1209 \mathrm{Ma}$. In contrast, twelve Lu-Hf isotopic data of the He 8 Member samples yielded the $\mathrm{T}_{\mathrm{DM} 2}$ of 1125-1821 Ma. Of which, eleven zircon grains yielded negative $\varepsilon_{\mathrm{Hf}}(\mathrm{t})$ values from -11.72 to -2.8 (average -7.47 ), with the $\mathrm{T}_{\mathrm{DM} 2}$ of 1364-1821 Ma (Table S2 and Figure 9). The remaining one zircon provided a positive $\varepsilon_{\mathrm{Hf}}(\mathrm{t})$ value of 1.88 , with a $\mathrm{T}_{\mathrm{DM} 2}$ of $1125 \mathrm{Ma}$, indicating a Mesoproterozoic crustal component. The $\varepsilon_{\mathrm{Hf}}(\mathrm{t})$ values of 520-378 Ma in the NQinOB, NQiOB and Yinshan Block are -27.56-14.6 (average -2.11, most of $\varepsilon_{\mathrm{Hf}}(\mathrm{t})$ between -15-10), -18.06-8.6 (average -3.3, most of $\varepsilon_{\mathrm{Hf}}(\mathrm{t})$ between -15-8) and -6.11-6.8 (average 1.03, most of $\varepsilon_{\mathrm{Hf}}(\mathrm{t})>0$ ), and the $\mathrm{T}_{\mathrm{DM} 2}$ are 551-2759 Ma (average $1391 \mathrm{Ma}$, most of $\mathrm{T}_{\mathrm{DM} 2}$ between $0.8-2.0 \mathrm{Ga}$ ), 742-2597 Ma (average $1557 \mathrm{Ma}$, most of $\mathrm{T}_{\mathrm{DM} 2}$ between 0.8-2.4 Ga ) and 1000-1793 Ma (average 1361 $\mathrm{Ma}$, most of $\mathrm{T}_{\mathrm{DM} 2}$ between $1.0-1.8 \mathrm{Ga}$ ), respectively (Table 2).

It can be infered that the provenance of 520-378 Ma detrital zircons might mainly come from both the NQinOB and NQiOB. Firstly, the crystallization age distribution, Lu-Hf isotope, and Hf model ages of the 520-378 Ma detrital zircons in the SOB agree well with that of the NQiOB and NQinOB, but they are obviously different from that of the Yinshan Block (Figures 8 and 9). Besides, it is difficult to distinguish the provenance contribution between the NQiOB and NQinOB using this information. Secondly, there are many magmatic zircons with ages from $400 \mathrm{Ma}$ to $520 \mathrm{Ma}$, and they show several distinct age peaks at $\sim 430-410 \mathrm{Ma}, \sim 450 \mathrm{Ma}$ and $\sim 500 \mathrm{Ma}$ in both the NQiOB and the NQinOB (Figure 8h,i). Furthermore, there are also some metamorphic and magmatic zircons' ages between $400 \mathrm{Ma}$ and $350 \mathrm{Ma}$ in the NQinOB, but few in the NQiOB (Figure 8h,i). Of all samples, three metamorphic origin zircons have ages of $443 \mathrm{Ma}, 404.4 \mathrm{Ma}$, and 391.6 Ma. The $450 \mathrm{Ma}$ and $\sim 430-400$ metamorphic events widely occurred both in the NQinOB [78,144] and the NQiOB [111,145-147], and 390 Ma metamorphic ages were reported in the NQinOB [74,79]. Therefore, we suggest that the provenance of 520-378 Ma zircons was from the NQinOB, and it is impossible to judge whether the NQiOB had provided any materials. Thirdly, although the $\varepsilon_{\mathrm{Hf}}(\mathrm{t})$ and $\mathrm{T}_{\mathrm{DM} 2}$ values from the $\mathrm{SOB}$ and the surrounding orogenic belts have a wide range, the Yinshan Block lacks the distribution of $\varepsilon_{\mathrm{Hf}}(\mathrm{t})<-6.2$ and $>10$, and $\mathrm{T}_{\mathrm{DM} 2}$ 
$<1.0 \mathrm{Ga}$ and $>1.8 \mathrm{Ga}$, while the NQinOB and NQiOB have such a distribution (Figure 9). Finally, the source studies of the SOB by sedimentological methods show that the NQiOB provided some materials for the Southwestern Ordos Basin [4-11]. Therefore, we infer that the provenance of 520-378 Ma detrital zircons likely derived from both the NQinOB and the NQiOB, while the NQiOB provided material only for the local area (e.g., Southwestern Ordos Basin). The 520-378 Ma ages are considered to be a representative attributed to continental collision and accretion in the NQinOB and NQiOB during the Paleozoic. The ages of 480-400 Ma are consistent with the Ordovician-Early Devonian tectonic events resulted from continental collision and accretion occurred in both the NQinOB and the NQiOB (Figure 8h,i). Whereas, the five zircons' ages between $400 \mathrm{Ma}$ and $378 \mathrm{Ma}$ represent the Middle Devonian tectonothermal events occurred in NQinOB.

In summary, we suggest that the detrital zircons of 520-378 Ma in the SOB likely derived from both the NQinOB and the NQiOB.

Table 2. Summarized the characters of Hf isotopic compositions.

\begin{tabular}{|c|c|c|c|c|c|}
\hline Ages (Ma) & Parameters & NQinOB & NQiOB & YB & SOB \\
\hline \multirow{4}{*}{$520-370$} & $\mathrm{e}_{\mathrm{Hf}}(\mathrm{t})$ value & $\begin{array}{l}-27.56-14.6^{\mathrm{a}} \\
-2.11^{\mathrm{b}}\left(522^{\mathrm{c}}\right)\end{array}$ & $\begin{array}{l}-18.06-8.6 \\
-3.3(184)\end{array}$ & $\begin{array}{l}-6.11-6.8 \\
1.03(35)\end{array}$ & $\begin{array}{c}-12.32-11.37 \\
-4.62(20)\end{array}$ \\
\hline & $\mathrm{e}_{\mathrm{Hf}}(\mathrm{t})$ feature & $\begin{array}{c}90 \% \text { between } \\
-15-10\end{array}$ & $\begin{array}{c}97 \% \text { between } \\
-15-8\end{array}$ & $\begin{array}{c}60 \%>0 \text {, all } \\
\text { between }-6.2-7\end{array}$ & $\begin{array}{c}50 \%<-6.2,5 \%> \\
10\end{array}$ \\
\hline & $\mathrm{T}_{\mathrm{DM} 2}$ value & $\begin{array}{c}551-2759 \mathrm{Ma}^{\mathrm{d}} \\
1391 \mathrm{Ma}^{\mathrm{e}}\left(522^{\mathrm{c}}\right)\end{array}$ & $\begin{array}{l}742-2597 \mathrm{Ma} \\
1557 \mathrm{Ma}(184)\end{array}$ & $\begin{array}{c}1000-1793 \mathrm{Ma} \\
1361 \mathrm{Ma}(35)\end{array}$ & $\begin{array}{l}\text { 679-1843 Ma } \\
1465 \mathrm{Ma}(20)\end{array}$ \\
\hline & $\mathrm{T}_{\mathrm{DM} 2}$ feature & $\begin{array}{l}94 \% \text { between } \\
0.8-2.0 \mathrm{Ga}\end{array}$ & $\begin{array}{c}90 \% \text { between } \\
0.8-2.4 \mathrm{Ga}\end{array}$ & $\begin{array}{l}\text { all between } \\
1.0-1.8 \mathrm{Ga}\end{array}$ & $\begin{array}{c}90 \% \text { between } \\
1.1-1.85 \mathrm{Ga}, 5 \%< \\
1.0 \mathrm{Ga}\end{array}$ \\
\hline \multirow{4}{*}{$350-320$} & $\mathrm{e}_{\mathrm{Hf}}(\mathrm{t})$ value & $\begin{array}{l}-7.9-(-5.8) \\
-6.7(13)\end{array}$ & / & $\begin{array}{l}-9.81-3.2 \\
-2.6(141)\end{array}$ & $\begin{array}{l}-15.13-2.92 \\
-7.05(30)\end{array}$ \\
\hline & $\mathrm{e}_{\mathrm{Hf}}(\mathrm{t})$ feature & $\begin{array}{l}\text { all between } \\
-8-(-5)\end{array}$ & / & $\begin{array}{c}\text { all between } \\
-10-3.2,73 \%< \\
0\end{array}$ & $90 \%<0,33 \%<-10$ \\
\hline & $\mathrm{T}_{\mathrm{DM} 2}$ value & $\begin{array}{c}1440-1540 \mathrm{Ma} \\
1485 \mathrm{Ma}(13)\end{array}$ & / & $\begin{array}{l}1131-1953 \mathrm{Ma} \\
1505 \mathrm{Ma} \mathrm{(141)}\end{array}$ & $\begin{array}{l}\text { 989-1908 Ma } \\
1498 \mathrm{Ma}(30)\end{array}$ \\
\hline & $\mathrm{T}_{\mathrm{DM} 2}$ feature & $\begin{array}{l}\text { all between } \\
1.4-1.55 \mathrm{Ga}\end{array}$ & l & $\begin{array}{l}91 \% \text { between } \\
1.2-1.85 \mathrm{Ga} \text {, all } \\
>1.1 \mathrm{Ga}\end{array}$ & $\begin{array}{c}80 \% \text { between } \\
1.13-1.77 \mathrm{Ga}, 10 \%< \\
1.1 \mathrm{Ga}\end{array}$ \\
\hline \multirow{4}{*}{$320-285$} & $\mathrm{e}_{\mathrm{Hf}}(\mathrm{t})$ value & / & / & $\begin{array}{c}-25.49-(-3.97) \\
-7.85(37)\end{array}$ & $\begin{array}{c}-20.84-5.18 \\
-8.65(56)\end{array}$ \\
\hline & $\mathrm{e}_{\mathrm{Hf}}(\mathrm{t})$ feature & / & / & $\begin{array}{l}81 \% \text { between } \\
-8.5-(-4)\end{array}$ & $\begin{array}{c}95 \%<0,16.1 \%> \\
-4.4,52 \%<-8.5 \\
79 \% \text { between } \\
-15-(-5)\end{array}$ \\
\hline & $\mathrm{T}_{\mathrm{DM} 2}$ value & / & I & $\begin{array}{l}1529-2046 \mathrm{Ma} \\
1746 \mathrm{Ma}(37)\end{array}$ & $\begin{array}{l}859-2178 \mathrm{Ma} \\
1557 \mathrm{Ma}(56)\end{array}$ \\
\hline & $\mathrm{T}_{\mathrm{DM} 2}$ feature & / & I & $\begin{array}{c}84 \% \text { between } \\
1.55-1.85 \mathrm{Ga} \text {, all } \\
>1.52 \mathrm{Ga}\end{array}$ & $\begin{array}{c}42 \%<1.52 \mathrm{Ga}, 89 \% \\
\text { between } 1.1-1.85 \\
\mathrm{Ga}\end{array}$ \\
\hline \multirow{4}{*}{$285-260$} & $\mathrm{e}_{\mathrm{Hf}}(\mathrm{t})$ value & I & / & $\begin{array}{l}-22.04-5.44 \\
-7.14(250)\end{array}$ & $\begin{array}{l}-13.88-4.3 \\
-6.92(7)\end{array}$ \\
\hline & $\mathrm{e}_{\mathrm{Hf}}(\mathrm{t})$ feature & l & l & $\begin{array}{c}94 \% \text { between } \\
-16-5\end{array}$ & $\begin{array}{c}86 \% \text { between } \\
-14-(-5)\end{array}$ \\
\hline & $\mathrm{T}_{\mathrm{DM} 2}$ value & l & l & $\begin{array}{l}\text { 954-2470 Ma } \\
1772 \mathrm{Ma}(250)\end{array}$ & $\begin{array}{l}877-1804 \mathrm{Ma} \\
1450 \mathrm{Ma}(7)\end{array}$ \\
\hline & $\mathrm{T}_{\mathrm{DM} 2}$ feature & l & l & $\begin{array}{c}95 \% \text { between } \\
1.0-2.3 \mathrm{Ga}\end{array}$ & $\begin{array}{l}86 \% \text { between } \\
1.35-1.81 \mathrm{Ga}\end{array}$ \\
\hline
\end{tabular}

"a" and " $\mathrm{d}$ " are numerical ranges of $\mathrm{e}_{\mathrm{Hf}}(\mathrm{t})$ and $\mathrm{T}_{\mathrm{DM} 2}$, respectively; " $\mathrm{b}$ " and " $\mathrm{e}$ " are numerical averages of $\mathrm{e}_{\mathrm{Hf}}(\mathrm{t})$ and

$\mathrm{T}_{\mathrm{DM} 2}$, respectively; " $\mathrm{c}$ " is the number of data.

\subsection{The Provenance of $350-260$ Ma Zircons}

The $\sim 350-260$ Ma zircon ages in the SOB show peaks at $320 \mathrm{Ma}, \sim 310-300 \mathrm{Ma}$ and $\sim 290 \mathrm{Ma}$ (Figure $8 \mathrm{a}, \mathrm{b}, \mathrm{f}$ ). The $\sim 350-260$ Ma detrital zircon grains from the Shan 1 Member (42 grains) and 
He 8 Member (91 grains) account for $10.4 \%$ and $14.1 \%$ of the total, respectively. Most zircons have dark or blurry oscillatory zoning and Th/U ratios $>0.4$ (Table S1, Figures 6 and 7), indicating main magmatic zircons. Two zircons may be of metamorphic origin (Figure $6 \mathrm{~m}$ ) and yielded the ages of $301.1 \pm 2.6 \mathrm{Ma}$ and $284.2 \pm 3.3 \mathrm{Ma}$. Thirty-one zircon Lu-Hf isotopic compositions from the Shan 1 Member were analyzed and yielded the $\mathrm{T}_{\mathrm{DM} 2}$ of 1046-2178 Ma, and most of the $\mathrm{T}_{\mathrm{DM} 2}$ range from $1.3 \mathrm{Ga}$ to $1.8 \mathrm{Ga}$. Of which, 29 zircons yielded negative $\varepsilon_{\mathrm{Hf}}(\mathrm{t}$ ) values from -20.84 to -0.19 (average -9.07 ), with the $\mathrm{T}_{\mathrm{DM} 2}$ of $1152-2178 \mathrm{Ma}$ (Table $\mathrm{S} 2$ and Figure 9). The remaining two grains provided positive $\varepsilon_{\mathrm{Hf}}(\mathrm{t})$ values of 1.46 and 1.51, with the $\mathrm{T}_{\mathrm{DM} 2}$ of $1063 \mathrm{Ma}$ and $1046 \mathrm{Ma}$. In contrast, 61 zircons from the He 8 Member yielded $\varepsilon_{\mathrm{Hf}}(\mathrm{t})$ values from -16.6 to 5.18 (average -7.77 , most of $\varepsilon_{\mathrm{Hf}}(\mathrm{t})<0$ ), with the $\mathrm{T}_{\mathrm{DM} 2}$ of $859-1948 \mathrm{Ma}$ (average $1515 \mathrm{Ma}$, most of $\mathrm{T}_{\mathrm{DM} 2}$ between 1.2-1.85 Ga). Of which, 56 zircons yielded negative $\varepsilon_{\mathrm{Hf}}(\mathrm{t})$ values ranging from -16.6 to -0.78 and with the $\mathrm{T}_{\mathrm{DM} 2}$ of $1164-1948$ $\mathrm{Ma}$ (average $1564 \mathrm{Ma}$, Table S2 and Figure 9). The others five grains provided positive $\varepsilon_{\mathrm{Hf}}(\mathrm{t})$ values of $1.28-5.18$, with the $\mathrm{T}_{\mathrm{DM} 2}$ of 859-1068 Ma (average $969 \mathrm{Ma}$ ).

Huge magmatism occurred in the Yinshan Block during the 350-230 Ma, due to the orogenesis of the Central Asia Orogenic Belt [141-143]. However, in contrast to the Yinshan Block, few contemporaneous magmatism events occurred in the other regions surrounding the Ordos Basin (Figure 8h-j). The 350-260 Ma detrital zircons of the Shan 1 and He 8 Member are very common in the Northern Ordos Basin [3] (Figure 8c-e). Luo et al. argued that the provenance of the $\sim 350-260$ Ma zircons in the Northern Ordos Basin was from the Yinshan Block [3].

In terms of the $\sim 350-260$ Ma detrital zircons' Hf isotopic compositions (Figure 9) and crystallization age distribution (Figure 8) in the Yinshan Block and SOB, they have obvious differences. Firstly, huge magmatism occurred in the Yinshan Block mainly dated $\sim 340-320$ Ma and $\sim 285-260$ Ma (Figure 8j), but the age populations in the SOB are dominantly distributed in $\sim 320-285 \mathrm{Ma}$ (Figure $8 \mathrm{a}, \mathrm{b}, \mathrm{f})$. In addition, the proportion of $\sim 320-285$ Ma detrital zircons preserved in the Northern Ordos Basin (6.8\%) [3] is lower than that of in the SOB $(10 \%)$, which may have two possibilities: one is that the provenance of the above two regions derived from different sources, and another possibility is that the sources of the two regions came from the same provenance, but the supplying source direction was from south to north, which is just opposite to the previous research result that the source supplying directions for the Shan 1-He 8 Member in the SOB were from southwest to northeast, southeast to northwest and south to north [4-11]. Therefore, we speculate that the provenance of $\sim 320-285$ Ma detrital zircons in the Northern Ordos Basin and SOB was different. Secondly, the $\varepsilon_{\mathrm{Hf}}(\mathrm{t})$ of 350-320 Ma and 320-285 Ma in the Yinshan Block are from -9.81 to 3.2 (average -2.6 , all $\varepsilon_{\mathrm{Hf}}(\mathrm{t})>-10$ ) and -25.49 to -3.97 (average -7.86 , most of $\varepsilon_{\mathrm{Hf}}(\mathrm{t})$ between -8.5 to -4 ), and that in the SOB are from -15.13 to 2.92 (average $-7.05,33 \%$ of $\varepsilon_{\mathrm{Hf}}(\mathrm{t})<-10$ ) and -20.84 to 5.18 (average $-8.65,52 \%$ of $\varepsilon_{\mathrm{Hf}}(\mathrm{t})<-8.5$ ), respectively (Table 2). The $\mathrm{T}_{\mathrm{DM} 2}$ of 350-320 Ma and 320-285 Ma zircons in the Yinshan Block are 1131-1953 Ma (average $1505 \mathrm{Ma}$, most of $\mathrm{T}_{\mathrm{DM} 2}$ between 1.2-1.85 Ga, all $\mathrm{T}_{\mathrm{DM} 2}>$ $1.1 \mathrm{Ga}$ ) and 1529-2046 Ma (average $1746 \mathrm{Ma}$, most of $\mathrm{T}_{\mathrm{DM} 2}$ between 1.55-1.85 Ga, all $\mathrm{T}_{\mathrm{DM} 2}>1.52 \mathrm{Ga}$ ), and that in the SOB are 989-1908 Ma (average $1498 \mathrm{Ma}$, most of $\mathrm{T}_{\mathrm{DM} 2}$ between $1.13-1.77 \mathrm{Ga}, 10 \%$ of $\mathrm{T}_{\mathrm{DM} 2}$ $<1.1 \mathrm{Ga}$ ) and $859-2178 \mathrm{Ma}$ (average $1557 \mathrm{Ma}, 42 \%$ of $\mathrm{T}_{\mathrm{DM} 2}<1.52 \mathrm{Ga}$ ), respectively (Table 2). Instead of the Yinshan Block, there are 33\% of $\varepsilon_{\mathrm{Hf}}(\mathrm{t})<-10$ and $10 \%$ of $\mathrm{T}_{\mathrm{DM} 2}<1.1 \mathrm{Ga}$ of the 350-320 Ma zircons in the SOB. Besides, there is $79 \%$ of $\varepsilon_{\mathrm{Hf}}(\mathrm{t})$ from -15 to $-5,52 \%$ of $\varepsilon_{\mathrm{Hf}}(\mathrm{t})<-8.5$, and $42 \%$ of $\mathrm{T}_{\mathrm{DM} 2}<1.52 \mathrm{Ga}$ of the 320-285 Ma zircons in the SOB, but it is significantly different from the Yinshan Block (Table 2). Therefore, it can be infered that the provenance of $\sim 350-260$ Ma detrital zircons is not coming from the Yinshan Block.

Thus we suggest that the provenance of $\sim 350-260$ Ma zircons is from the NQinOB. Firstly, an age group of $\sim 350-260 \mathrm{Ma}$ of the detrital zircons from the Carboniferous-Triassic sandstones also presented in the Liuyehe Basin $[13,14]$ (Figure 8g). Besides, the $350-260$ Ma detrital zircon content $(23.2 \%$ ) in the Liuyehe Basin $[13,14]$ is higher than that of in the SOB $(12.7 \%)$. Gao et al. and Li et al. indicated that the provenance of Carboniferous-Triassic ( 350-260 Ma) zircons in the Liuyehe Basin was from the NQinOB, and the Liuyehe Basin and SOB have the same source $[13,14]$. Secondly, there are a few reports about metamorphic ages between $350 \mathrm{Ma}$ and $260 \mathrm{Ma}$ in the NQinOB (Figure 8d), such as the ages of $324 \mathrm{Ma}$ by U-Pb isotopic ratios titanite dating [68], 335-345 Ma [85], $341.7 \pm 3 \mathrm{Ma}$ [85] 
and 330-348 Ma [65] by LA-ICP-MS zircon dating, and $347 \pm 6$ Ma by SHRIMP zircon dating [70]. Moreover, Zhang et al. obtained $312 \mathrm{Ma}$ and $263 \pm 2 \mathrm{Ma}$ ages in the NQinOB amphibolite by the method of mineral $\mathrm{Rb}-\mathrm{Sr}$ isochron [148]. These indicate that tectonothermal events may have occurred in the NQinOB during 350-260 Ma, particularly during 320-260 Ma. Finally, the source supplying directions of the Shan 1 and He 8 Member in the SOB show that the clastic sources were from the southwestern, southeastern and southern orogenic belts surrounding the SOB [4-11].

In summary, the $~ 350-260$ Ma zircons of the Upper Paleozoic in the SOB might originate from the NQinOB. Besides, there are both magmatic origin and metamorphic origin zircons of $\sim 320-260 \mathrm{Ma}$ in the Shan 1-He 8 Member. Furthermore, the magmatism and metamorphism of $~ 320-260$ Ma possibly occurred in the NQinOB, even though, to date, there have been few reports on tectonothermal events of the $\sim 320-260$ Ma period. Therefore, we tentatively speculate that the $\sim 320-260$ Ma age records tracing the Carboniferou-Permian tectonothermal events might be preserved in some geologic bodies in the NQinOB, unfortunately, few records have been found due to the intensified denudation during the later orogenic uplift.

\section{Conclusions}

The 520-378 Ma detrital zircons preserved in the Upper Paleozoic in the Southern Ordos Basin are representatives of source contribution from both the NQinOB and the NQiOB. While the $~ 350-260 \mathrm{Ma}$ detrital zircons in the Southern Ordos Basin are agree very well to those coeval zircons recognized from the Carboniferous-Triassic sandstones in Liuyehe intermountain basin, which suggested that not only the NQinOB turn into the major source for the Southern Ordos Basin during the Late Paleozoic, but important tectonothermal events also occurred from $320 \mathrm{Ma}$ to $260 \mathrm{Ma}$ in the NQinOB after oceanic subduction and continental collision during Early Paleozoic.

Supplementary Materials: The following are available online at http://www.mdpi.com/2075-163X/10/3/265/s1, Table S1: LA-ICP-MS zircon U-Pb data of the samples, Table S2: In situ Lu-Hf isotopes analytical data for detrital zircons of samples.

Author Contributions: Z.J. conceived the research rout of this article under the direction of J.L. Z.J., Y.H. and S.M. made field investigation and collected samples; J.L., X.L. and Z.J. conceived and designed the experiments; Z.J. interpreted all the data and finished the original draft of the paper; X.L., X.H., Y.H. and L.F. reviewed the original draft and provided some scientific research data and acted as the project administration; Z.J., S.M. and Y.H. performed the zircon $\mathrm{U}-\mathrm{Pb}$ dating and $\mathrm{Lu}-\mathrm{Hf}$ isotope analysis. J.L. made a final modification and examination, and approval of manuscript. All authors have read and agreed to the published version of the manuscript.

Funding: This research is funded by the National Science and Technology Major Project (2017ZX05008-004-004-001) and the Technology Major Project of China Petroleum and Natural Gas Co., Ltd. (2016E-05-02).

Acknowledgments: We are grateful to Kai Cui and Chong Wang for their help during the fieldwork and sample preparation, LA-ICP-MS U-Pb and Lu-Hf isotopic dating. We would like to thank Xinyu Liu, Hao Liu, Huan Yang and Hang Zhou who gave us many helps during dada processing of the zircon ages and Lu-Hf isotopes. Many thanks also give to Chengli Zhang for his valuble and constructive comments and suggestions to the manuscript.

Conflicts of Interest: The authors declare no conflict of interest.

\section{References}

1. Bao, C.; Chen, Y.L.; Li, D.P.; Wang, S.H. Provenances of the Mesozoic sediments in the Ordos Basin and implications for collision between the North China Craton (NCC) and the South China Craton (SCC). J. Asian Earth Sci. 2014, 96, 296-307. [CrossRef]

2. Xie, X.Y.; Heller, P.L. U-Pb detrital zircon geochronology and its implications: The early Late Triassic Yanchang Formation, south Ordos Basin, China. J. Asian Earth Sci. 2013, 64, 86-98. [CrossRef]

3. Luo, J.L.; Wei, X.S.; Yao, J.L.; Liu, X.S.; Liu, X.H. Provenance and depositional facies controlling on the Upper Paleozoic excellent natural gas-reservoir in northern Ordos basin, China. Geol. Bull. China 2010, 29, 811-820, (In Chinese with English Abstract).

4. Yan, J.P. Sedimentary-tectonic Evolution and Gas-potential Exporation of Late Paleozoic in Southern Ordos Basin. Ph.D. Thesis, Northwest University, Xi'an, China, 2010. (In Chinese with English Abstract).

5. Luo, T.T. Prototype and Evolution of Shihezi Formation, Yanchang Formation Basin in Southern Ordos and Its Adjacent Region. Master's Thesis, Northwest University, Xi'an, China, 2011. (In Chinese with English Abstract). 
6. Chen, Q.H.; Li, W.H.W.; Liu, H.; Li, K.Y.; Pang, J.G.; Guo, Y.Q.; Yuan, Z. Provenance analysis of sandstone of the Upper Carboniferous to Middle Permian in Ordos Basin. J. Palaeogr. 2009, 11, 629-640. [CrossRef]

7. Li, Y.L.; Yu, X.H.; Shan, X.; Du, Y.H.; Zhou, J.S.; Han, X.Q. Provence and sedimentary facies of He 8 member of Xiashihezi Formation in sourtheastern Ordos basin. J. Northeast Pet. Univ. 2016, 40, 51-60. [CrossRef]

8. Qu, H.J.; Ma, Q.; Gao, S.L.; Mei, Z.C.; Miao, J.N. On provenance of the Permian in the southeastern Ordos Basin. Acta Geol. Sin. 2011, 85, 979-986, (In Chinese with English Abstract).

9. Cui, K. Provenance of the Upper Paleozoic Shan 1-He 8 Formation in Southern Ordos Basin and Its Influence on the Sedimentary Filling Pattern in the Southern Ordos Basin. Master's Thesis, Northwest University, $X_{i}$ 'an, China, 2019. (In Chinese with English Abstract).

10. Wang, R.; Luo, S.S.; Wang, X.; Lv, Q.Q.; Wang, H.W.; Liu, B.X.; Liu, J. Analysis and identification of provenance of 8th Member of Shihezi Formation in the Southwestern Ordos Basin. J. Oil Gas Technol. 2014, 36, 26-29, (In Chinese with English Abstract).

11. Yang, R.; Peng, D.T.; Pan, R.F.; Shi, S.Y.; Zhang, L. Sediment provenance analysis of the 8th Member of the Upper Paleozoic Xiashihezi Formation in the southwest area of Ordos basin. Pet. Geol. Eng. 2012, 26, 1-5, (In Chinese with English Abstract).

12. Dai, R.; Pan, Z.Y.; Lv, Q.Q.; Peng, Y.H. Analysis on Provenances for the Upper Palaeozoic Shan 1 and He 8 Members in the Southwestern Part of the Ordos Basin: Evidences from Rare Earth Elements and Timings of Zircon Rocks. Electron. J. Geotech. Eng. 2016, 21, 6111-6126.

13. Gao, C.Y.; Guo, A.L.; Li, X.H.; Li, K.; Liu, W.G. LA-ICP-MS U-Pb dating of detrital zircon from Liuyehe basin in North Qinling Mountains. Geol. Bull. China 2015, 34, 1689-1698, (In Chinese with English Abstract).

14. Li, K.; Guo, A.L.; Gao, C.Y.; Li, X.H. A tentative discussion on the source area of the Late Triassic Liuyehe basin in North Qinling Mountains and its relationship with the Ordos basin: Evidence from LA-ICP-MS U-Pb dating of detrital zircons. Geol. Bull. China 2015, 34, 1426-1437, (In Chinese with English Abstract).

15. Fanning, C.M.; Flint, R.B.; Parker, A.J.; Ludwig, K.R.; Blissett, A.H. Refind Proterozoic evolution of the Gawler Craton, South Australia, through U-Pb zircon geochronology. Precambrian Res. 1988, 40, 363-386. [CrossRef]

16. Gehrels, G.E.; Blakey, R.; Karlstrom, K.E.; Timmons, J.M.; Dickinson, B.; Pecha, M. Detrital zircon U-Pb geochronology of Paleozoic strata in the Grand Canyon. Lithosphere 2011, 3, 183-200. [CrossRef]

17. Thomas, W.A. Detrital-zircon geochronology and sedimentary provenance. Lithosphere 2011, 3, 304-308. [CrossRef]

18. Gehrels, G.E. Detrital zircon U-Pb geochronology: Current methods and new opportunities. In Tectonics of Sedimentary Basins: Recent Advances; Blackwell Publishing Ltd.: Oxford, UK, 2012; pp. 46-62.

19. Gehrels, G.E.; Mcclelland, W.C.; Samson, S.D.; Patchett, P.J. U-Pb geochronology of detrital zircons from a continental margin assemblage in the northern Coast Mountains, southeastern Alaska. Can. J. Earth Sci. 1991, 28, 1285-1300. [CrossRef]

20. Jackson, S.E.; Pearson, N.J.; Griffin, W.L.; Elena, A.B. The application of laser ablation-inductively coupled plasma-mass spectrometry to in situ U-Pb zircon geochronology. Chem. Geol. 2004, 211, 47-69. [CrossRef]

21. Thomas, W.A.; Becker, T.P.; Samson, S.D.; Hamilton, M.A. Detrital zircon evidence of a recycled orogenic foreland provenance for Alleghanian clastic-wedge sandstones. J. Geol. 2004, 112, 23-37. [CrossRef]

22. Guo, J.H.; Zhai, M.G.; Xu, R.H. Timing of the granulite facies metamorphism in the Sanggan area, North China craton: Zircon U-Pb geochronology. Sci. China Ser. D Earth Sci. 2001, 44, 1010-1018. [CrossRef]

23. Wang, T.; Zheng, Y.D.; Gehrels, G.E.; Mu, Z.G. Geochronological evidence for existence of South Mongolian microcontinent-A zircon $\mathrm{U}-\mathrm{Pb}$ age of grantoid gneisses from the Yagan-Onch Hayrhan metamorphic core complex. Chinese Sci. Bull. 2001, 46, 2005. [CrossRef]

24. Zhang, J.; Li, J.Y.; Liu, J.F.; Feng, Q.W. Detrital zircon U-Pb ages of Middle Ordovician flysch sandstones in the western ordos margin: New constraints on their provenances, and tectonic implications. J. Asian Earth Sci. 2011, 42, 1030-1047. [CrossRef]

25. Long, X.P.; Yuan, C.; Sun, M.; Xiao, W.J.; Zhao, G.C.; Wang, Y.J.; Cai, K.D.; Xia, X.P.; Xie, L.W. Detrital zircon ages and $\mathrm{Hf}$ isotopes of the early Paleozoic flysch sequence in the Chinese Altai, NW China: New constrains on depositional age, provenance and tectonic evolution. Tectonophysics 2010, 480, 213-231. [CrossRef]

26. Dickinson, W.R.; Gehrels, G.E. U-Pb ages of detrital zircons in Jurassic eolian and associated sandstones of the Colorado Plateau: Evidence for transcontinental dispersal and intraregional recycling of sediment. Geol. Soc. Am. Bull. 2015, 121, 408-433. [CrossRef] 
27. Howard, K.E.; Hand, M.; Barovich, K.M.; Reid, A.; Wade, B.P.; Belousova, E.A. Detrital zircon ages: Improving interpretation via Nd and Hf isotopic data. Chem. Geol. 2009, 262, 277-292. [CrossRef]

28. Wan, Y.S.; Liu, D.Y.; Wang, W.; Song, T.R.; Kröner, A.; Dong, C.Y.; Zhou, H.Y.; Yin, X.Y. Provenance of Mesoto Neoproterozoic cover sediments at the Ming Tombs, Beijing, North China Craton: An integrated study of $\mathrm{U}-\mathrm{Pb}$ dating and $\mathrm{Hf}$ isotopic measurement of detrital zircons and whole-rock geochemistry. Gondwana Res. 2011, 20, 219-242. [CrossRef]

29. Zhang, C.L.; Diwu, C.R.; Kröner, A.; Sun, Y.; Luo, J.L.; Li, Q.L.; Gou, L.L.; Lin, H.B.; Wei, X.S.; Zhao, J. Archean-Paleoproterozoic crustal evolution of the Ordos Block in the North China Craton: Constraints from zircon U-Pb geochronology and Hf isotopes for gneissic granitoids of the basement. Precambrian Res. 2015, 267, 121-136. [CrossRef]

30. He, C.; Ji, L.M.; Wu, Y.D.; Su, A.; Zhang, M.Z. Characteristics of hydrothermal sedimentation process in the Yanchang Formation, south Ordos Basin, China: Evidence from element geochemistry. Sediment. Geol. 2016, 345, 33-41. [CrossRef]

31. Guo, P.; Liu, C.Y.; Wang, J.Q.; Deng, Y.; Zhao, X.C.; Wang, L. Sedimentary boundary evolution of the Carboniferous in the Northern North-South Tectonic Belt, China and its geological significance. Earth Sci. Front. 2015, 22, 215-226. [CrossRef]

32. Lin, C.S.; Yang, Q.; Li, S.T.; Li, Z. Sedimentary characters of the Early Paleozoic deep water gravity flow systems and basin filling style in the Helan aulacogen, Northwest China. Geoscience 1991, 5, 252-262, (In Chinese with English Abstract).

33. Lin, C.S.; Yang, Q.; Li, S.T. Basin Filling and Evolution Analysis of Helan Aulacogen, Northwest China; Geological Publishing House: Beijing, China, 1995; pp. 1-143. (In Chinese)

34. Guo, P.; Liu, C.Y.; Wang, J.Q.; Deng, Y.; Mao, G.Z.; Wang, W.Q. Detrital-zircon geochronology of the Jurassic coal-bearing strata in the western Ordos Basin, North China: Evidences for multi-cycle sedimentation. Geosci. Front. 2018, 9, 1725-1743. [CrossRef]

35. Chen, Q.H. Research on Sedimentary Systems and Hydrocarbons Enrichment of the Upper Palaeozoic of the Ordos Basin. Ph.D. Thesis, Northwest University, Xi'an, China, 2007. (In Chinese with English Abstract).

36. Zhao, G.C.; Sun, M.; Wilde, S.A.; Li, S.Z. Late Archean to Paleoproterozoic evolution of the North China Craton: Key issues revisited. Precambrian Res. 2005, 136, 177-202. [CrossRef]

37. Guan, H.; Sun, M.; Simon, A.W.; Zhou, X.H.; Zhai, M.G. SHRIMP U-Pb zircon geochronology of the Fuping Complex: Implications for formation and assembly of the North China Craton. Precambrian Res. 2002, 113, 1-18. [CrossRef]

38. Wang, W.; Zhou, M.F.; Yan, D.P.; Li, J.W. Depositional age, provenance, and tectonic setting of the Neoproterozoic Sibao Group, southeastern Yangtze Block, South China. Precambrian Res. 2012, 192, 107-124. [CrossRef]

39. Yuan, H.L.; Gao, S.; Liu, X.M.; Li, H.M.; Günther, D.; Wu, F.Y. Accurate U-Pb Age and Trace Element Determinations of Zircon by Laser Ablation-Inductively Coupled Plasma-Mass Spectrometry. Geostand. Geoanal. Res. 2004, 28, 353-370. [CrossRef]

40. Diwu, C.R.; Sun, Y.; Zhang, H.; Wang, Q.; Guo, A.L.; Fan, L.G. Episodic tectonothermal events of the western North China Craton and North Qinling Orogenic Belt in central China: Constraints from detrital zircon U-Pb ages. J. Asian Earth Sci. 2012, 47, 107-122. [CrossRef]

41. Thomas, R. Practical Guide to ICP-MS: A Tutorial for Beginners; CRC Press: Oxon, UK, 2013; p. 409.

42. Ludwig, K.R. User's Manual for Isoplot 3.00, A Geochronological Toolkit for Microsoft Excel; Berkeley Geochronological Center, Special Publication: Berkeley, CA, USA, 2003; Volume 4, pp. 1-70.

43. Bao, Z.A.; Chen, L.; Zong, C.L.; Yuan, H.L.; Chen, K.Y.; Dai, M.N. Development of pressed sulfide powder tablets for in situ sulfur and lead isotope measurement using LA-MC-ICP-MS. Int. J. Mass Spectrom. 2017, 421, 255-262. [CrossRef]

44. Yuan, H.L.; Gao, S.; Dai, M.N.; Zong, C.L.; Günther, D.; Fontaine, G.H.; Liu, X.M.; Diwu, C.R. Simultaneous determinations of $\mathrm{U}-\mathrm{Pb}$ age, $\mathrm{Hf}$ isotopes and trace element compositions of zircon by excimer laser-ablation quadrupole and multiple-collector ICP-MS. Chem. Geol. 2008, 247, 100-118. [CrossRef]

45. Blichert-Toft, J.; Albarede, F. The Lu-Hf isotope geochemistry of chondrites and the evolution of the mantle-crust system. Earth Planet. Sci. Lett. 1997, 148, 243-258. [CrossRef] 
46. Griffin, W.L.; Person, N.J.; Belousova, E.; Jackson, S.E.; Achterbergh, E.V.; Reilly, S.Y.O.; Shee, S.R. The Hf isotope composition of cratonic mantle: LAM-MC-ICPMS analysis of zircon megacrysts in kimberlites. Geochim. Cosmochim. Acta 2000, 64, 133-147. [CrossRef]

47. Söderlund, U.; Patchett, P.J.; Vervoort, J.D.; Isachsen, C.E. The ${ }^{176} \mathrm{Lu}$ decay constant determined by Lu-Hf and U-Pb isotope systematics of Precambrian mafic intrusions. Earth Planet. Sci. Lett. 2004, 219, 311-324. [CrossRef]

48. Amelin, Y.; Lee, D.C.; Halliday, A.N.; Pidgeon, R.T. Nature of the Earth's earliest crust from hafnium isotopes in single detrital zircons. Nature 1999, 399, 252-255. [CrossRef]

49. Wu, F.Y.; Li, X.H.; Zheng, Y.F.; Gao, S. Lu-Hf isotopic systematics and their applications in petrology. Acta Petrol. Sin. 2007, 23, 185-220, (In Chinese with English Abstract).

50. Fornelli, A.; Gallicchio, S.; Micheletti, F. U-Pb detrital zircon ages and compositional features of Bifurto quartz-rich sandstones from Southern Apennines (Southern Italy): Comparison with Numidian Flysch sandstones to infer source area. Ital. J. Geosci. 2019, 138, 216-230. [CrossRef]

51. Malusà, M.G.; Garzanti, E. The Sedimentology of Detrital Thermochronology. In Fission-Track Thermochronology and Its Application to Geology; Malusà, M.G., Fitzgerald, P.G., Eds.; Springer International Publishing AG: Berlin, Germany, 2019; pp. 123-143. [CrossRef]

52. El-Naby, H.H.A.; Dawood, Y.H. Testing the validity of detrital zircon chemistry as a provenance indicator. Arab. J. Geosci. 2014, 7, 341-353. [CrossRef]

53. Hoskin, P.W.O.; Schaltegger, U. The Composition of Zircon and Igneous and Metamorphic Petrogenesis. Rev. Mineral. Geochem. 2003, 53, 27-62. [CrossRef]

54. Hanchara, J.M.; Millerb, C.F. Zircon zonation patterns as revealed by cathodoluminescence and backscattered electron images: Implications for interpretation of complex crustal histories. Chem. Geol. 1993, 110, 1-13. [CrossRef]

55. Hoskin, P.W.O. Patterns of chaos: Fractal statistics and the oscillatory chemistry of zircon. Geochim. Cosmochim. Acta 2000, 64, 1905-1923. [CrossRef]

56. Pidgeon, R.T. Recrystallisation of oscillatory zoned zircon: Some geochronological and petrological implications. Contrib. Mineral. Petrol. 1992, 110, 463-472. [CrossRef]

57. Corfu, F.; Hanchar, J.M.; Hoskin, P.W.O.; Kinny, P. Atlas of zircon textures. Rev. Mineral. Geochem. 2003, 53, 469-500. [CrossRef]

58. Belousova, E.A.; Griffin, W.L.; Reilly, S.Y.O.; Fisher, N.I. Igneous zircon: Trace element composition as an indicator of source rock type. Contrib. Mineral. Petrol. 2002, 143, 602-622. [CrossRef]

59. Rubatto, D. Zircon trace element geochemistry: Partitioning with garnet and the link between U-Pb ages and metamorphism. Chem. Geol. 2002, 184, 123-138. [CrossRef]

60. Zhang, C.L.; Liu, L.; Wang, T.; Wang, X.X.; Li, L.; Gong, Q.F.; Li, X.F. Granitic magmatism related to early Paleozoic continental collision in North Qinling. Chin. Sci. Bull. 2013, 58, 4405-4410. [CrossRef]

61. Qin, Z.W.; Wu, Y.B.; Siebel, W.; Gao, S.; Wang, H.; Abdallsamed, M.I.M.; Zhang, W.X.; Yang, S.H. Genesis of adakitic granitoids by partial melting of thickened lower crust and its implications for early crustal growth: A case study from the Huichizi pluton, Qinling orogen, central China. Lithos 2015, 238, 1-12. [CrossRef]

62. Su, W.; Liu, J.B.; Chen, N.S.; Guo, S.; Ba, J.; Zhang, L.; Liu, X.; Shi, Y.X. Geochronology and tectonic background of magmatic and metamorphic events in the East Qinling-Dabie mountains. Acta Petrol. Sin. 2013, 29, 1573-1593. [CrossRef]

63. Liu, B.X. Magmatism and Crustal Evolution in the Eastern North Qinling Terrain. Ph.D. Thesis, University of Science and Technology of China, Beijing, China, 2014. (In Chinese with English Abstract).

64. Wang, H.; Wu, Y.B.; Gao, S.; Liu, X.C.; Liu, Q.; Qin, Z.W.; Xie, S.W.; Zhou, L.; Yang, S.H. Continental origin of eclogites in the North Qinling terrane and its tectonic implications. Precambrian Res. 2013, 230, 13-30. [CrossRef]

65. Zhang, H.F.; Yu, H.; Zhou, D.W.; Zhang, J.; Dong, Y.P.; Zhang, G.W. The meta-gabbroic complex of Fushui in north Qinling orogen: A case of syn-subduction mafic magmatism. Gondwana Res. 2015, 28, 262-275. [CrossRef]

66. Shi, Y.; Yu, J.H.; Santosh, M. Tectonic evolution of the Qinling orogenic belt, Central China: New evidence from geochemical, zircon U-Pb geochronology and Hf isotopes. Precambrian Res. 2013, 231, 19-60. [CrossRef] 
67. Diwu, C.; Sun, Y.; Zhao, Y.; Liu, B.X.; Lai, S.C. Geochronological, geochemical, and Nd-Hf isotopic studies of the Qinling Complex, central China: Implications for the evolutionary history of the North Qinling Orogenic Belt. Geosci. Front. 2014, 5, 499-513. [CrossRef]

68. Bader, T.; Franz, L.; Ratschbacher, L.; de Capitani, C.; Webb, A.A.G.; Yang, Z.; Pfänder, J.A.; Hofmann, M.; Linnemann, U. The Heart of China revisited: II Early Paleozoic (ultra) high-pressure and (ultra) high-temperature metamorphic Qinling orogenic collage. Tectonics 2013, 32, 922-947. [CrossRef]

69. Wen, Z.L.; Xu, X.Y.; Zhao, R.F.; Wang, F.; Hu, W. Geologic and geochemical features of Devonian granites in Dangchuan area, western Qinling, and its tectonic significance. Geol. Rev. 2008, 54, 827-836. [CrossRef]

70. Yan, Z.; Wang, Z.Q.; Chen, J.L.; Yan, Q.R.; Wang, T.; Zhang, Y.L. Geochemistry and SHRIMP zircon U-Pb dating of amphibolites from the Danfeng Group in the Wuguan area, North Qinling terrane and their tectonic significance. Acta Geol. Sin. 2009, 83, 1633-1646, (In Chinese with English Abstract).

71. Zhang, Z.Q.; Zhang, G.W.; Liu, D.Y.; Wang, Z.Q.; Tang, S.H.; Wang, J.H. Isotopic Chronology and Geochemistry of Ophiolite, Granite and Clastic Sedimentary Rocks in Qinling Orogenic Belt; Geological Publishing House: Beijing, China, 2006; pp. 1-340. (In Chinese)

72. Dong, Y.P.; Zhang, G.W.; Hauzenberger, C.; Neubauer, F.; Yang, Z.; Liu, X.M. Palaeozoic tectonics and evolutionary history of the Qinling orogen: Evidence from geochemistry and geochronology of ophiolite and related volcanic rocks. Lithos 2011, 122, 39-56. [CrossRef]

73. Faure, M.; Lin, W.; Monié, P.; Meffre, S. Palaeozoic collision between the North and South China blocks, Triassic intracontinental tectonics, and the problem of the ultrahigh-pressure metamorphism. C. R. Geosci. 2008, 340, 139-150. [CrossRef]

74. Li, T.; Santosh, M.; Dong, Y.P. Tectonic evolution of a complex orogenic system: Evidence from the northern Qinling belt, Central China. J. Asian Earth Sci. 2015, 113, 544-559. [CrossRef]

75. Liao, X.Y.; Liu, L.; Wang, Y.W.; Cao, Y.T.; Chen, D.L.; Dong, Y.P. Multi-stage metamorphic evolution of retrograde eclogite with a granulite-facies overprint in the Zhaigen area of the North Qinling Belt, China. Gondwana Res. 2016, 30, 79-96. [CrossRef]

76. Yu, H.; Zhang, H.F.; Li, X.H.; Zhang, J.; Santosh, M.; Yang, Y.H.; Zhou, D.W. Tectonic evolution of the North Qinling Orogen from subduction to collision and exhumation: Evidence from zircons in metamorphic rocks of the Qinling Group. Gondwana Res. 2016, 30, 65-78. [CrossRef]

77. Chen, D.L.; Liu, L. New data on the chronology of eclogite and associated rock from Guanpo Area, North Qinling orogeny and its constraint on nature of North Qinling HP-UHP eclogite terrane. Earth Sci. Front. 2011, 18, 158-169, (In Chinese with English Abstract).

78. Liu, L.; Liao, X.Y.; Zhang, C.L.; Chen, D.L.; Gong, X.K.; Kang, L. Multi-matemorphic timings of HP-UHP rocks in the North Qinling and their geological implications. Acta Petrol. Sin. 2013, 29, 1634-1656, (In Chinese with English Abstract).

79. Wang, Y.W. Multi-metamorphism of Amphibolites in Qinling Complex and Its Tectonic Implications. Master's Thesis, Northwest University, Xi'an, China, 2015. (In Chinese with English Abstract).

80. Xiang, H. Early Paleozoic Ploy-metamorphism and Tectonic Evolution of the Northern Qinling-Tongbai Orogenic Belt. Ph.D. Thesis, China University of Geosciences (Wuhan), Wuhan, China, 2012. (In Chinese with English Abstract).

81. Chen, D.L.; Ren, Y.F.; Gong, X.K.; Liu, L.; Gao, S. Identification and its geological significance of eclogite in Songshugou, the North Qinling. Acta Petrol. Sin. 2015, 31, 1841-1854, (In Chinese with English Abstract).

82. Chen, D.; Liu, L.; Sun, Y.; Zhang, A.D.; Liu, X.M.; Luo, J.H. LA-ICP-MS U-Pb dating of zircon from Songshugou high pressure basic granulite in the northern Qinling Mountains and its geological significance. Chin. Sci. Bull. 2004, 49, 1901-1908. (In Chinese)

83. Gong, X.K.; Chen, D.L.; Ren, Y.F.; Liu, L.; Gao, S.; Yang, S.J. Identification of coesite-bearing amphibolite in the North Qinling and its geological significance. China Sci. Bull. 2016, 61, 1365-1381, (In Chinese with English Abstract).

84. He, S.P.; Wang, H.L.; Chen, J.L.; Xu, X.Y.; Zhang, H.F.; Ren, G.M.; Yu, J.Y. Zircon U-Pb Chronology of Kuanping Rock Group By LA-ICP-MS and its Geological Significance. Acta Geol. Sin. 2007, 81, 80-87, (In Chinese with English Abstract).

85. Li, P.; Chen, J.L.; Xu, X.Y.; Wang, H.L.; Li, T.; Gao, T. Petrogenesis and LA-ICPMS zircon U-Pb dating of the Wuguan intrusive body in North Qinling. Acta Petrol. Mineral. 2011, 30, 610-624, (In Chinese with English Abstract). 
86. Li, Y.; Zhou, H.W.; Li, Q.L.; Xiang, H.; Zhong, Z.Q.; Brouwer, F.M. Palaeozoic polymetamorphism in the North Qinling orogenic belt, Central China: Insights from petrology and in situ titanite and zircon U-Pb geochronology. J. Asian Earth Sci. 2014, 92,77-91. [CrossRef]

87. Liu, J.F.; Sun, Y.; Tong, L.X.; Sun, W.D. Emplacement age of the Songshugou ultramafic massif in the Qinling orogenic belt, and geologic implications. Int. Geol. Rev. 2009, 51, 58-76, (In Chinese with English Abstract). [CrossRef]

88. Liu, Q.; Wu, Y.B.; Wang, H.; Gao, S.; Qin, Z.W.; Liu, X.C.; Yang, S.H.; Gong, H.J. Zircon U-Pb ages and Hf isotope compositions of migmatites from the North Qinling terrane and their geological implications. J. Metamorph. Geol. 2014, 32, 177-193. [CrossRef]

89. Liu, X.C.; Jahn, B.M.; Hu, J.; Li, S.Z.; Liu, X.; Song, B. Metamorphic patterns and SHRIMP zircon ages of medium-to-high grade rocks from the Tongbai orogen, central China: Implications for multiple accretion/ collision processes prior to terminal continental collision. J. Metamorph. Geol. 2011, 29, 979-1002. [CrossRef]

90. Song, C.Z.; Zhang, G.W.; Wang, Y.S.; Cai, Z.C. The constraints of strain partitioning and geochronology in Luonan-Luanchuan tectonic belts on Qinling orogenic belt. Sci. China Ser. D Earth Sci. 2009, 52, 300-312. [CrossRef]

91. Wang, H. Neoproterozoic-Early Paleozoic Metamorphism and Magmatism during the Multistage Evolution of the Eastern Qinling-Tongbai Orogenic Belt. Ph.D. Thesis, China University of Geosciences (Wuhan), Wuhan, China, 2014. (In Chinese with English Abstract).

92. Yang, J.S.; Liu, F.L.; Wu, C.L.; Xu, Z.Q.; Shi, R.D.; Chen, S.Y. Two Ultrahigh-Pressure Metamorphic Events Recognized in the Central Orogenic Belt of China: Evidence from the U-Pb Dating of Coesite-Bearing Zircons. Int. Geol. Rev. 2005, 47, 327-343. [CrossRef]

93. Yang, J.S.; Xu, Z.Q.; Pei, X.Z.; Shi, R.D.; Wu, C.L.; Zhang, J.X.; Li, H.B.; Meng, F.C.; Rong, H. Discovery of Diamond in North Qinling: Evidence for a Giant UHPM Belt across Central China and Reeognition of Paleozoic and Mesozoic Dual Deep Subduction between North China and Yangtze Plates. Acta Geol. Sin. 2002, 76, 485-495, (In Chinese with English Abstract).

94. Yan, Z.; Aitchison, J.; Fu, C.L.; Guo, X.Q.; Niu, M.L.; Xia, W.J.; Li, J.L. Hualong Complex, South Qilian terrane: $\mathrm{U}-\mathrm{Pb}$ and $\mathrm{Lu}-\mathrm{Hf}$ constraints on Neoproterozoic micro-continental fragments accreted to the northern Proto-Tethyan margin. Precambrian Res. 2015, 266, 65-85. [CrossRef]

95. Yang, H.; Zhang, H.F.; Luo, B.J.; Zhang, J.; Xiong, Z.L.; Guo, L.; Pan, F.B. Early Paleozoic intrusive rocks from the eastern Qilian orogen, NE Tibetan Plateau: Petrogenesis and tectonic significance. Lithos 2015, 224, $13-31$. [CrossRef]

96. Chen, Y.X.; Song, S.G.; Niu, Y.L.; Wei, C.J. Melting of continental crust during subduction initiation: A case study from the Chaidanuo peraluminous granite in the North Qilian suture zone. Geochim. Cosmochim. Acta 2014, 132, 311-336. [CrossRef]

97. He, S.P.; Wang, H.L.; Xu, X.Y.; Zhang, H.F.; Ren, G.M. A LA-ICP-MS U-Pb chronological study of zircons from Hongtubu basic volcanic rocks and its geological significance in the east segment of North Qilian orogenic belt. Adv. Earth Sci. 2007, 22, 143-151, (In Chinese with English Abstract).

98. Wu, C.L.; Xu, X.Y.; Gao, Q.M.; Li, X.M.; Lei, M.; Gao, Y.H.; Ronald, B.F.; Joseph, L.W. Early Palaezoic grranitoid magmatism and tectonic evolution in North Qilian, NW China. Acta Petrol. Sin. 2010, 26, 1027-1044, (In Chinese with English Abstract).

99. Xu, X.Y.; He, S.P.; Wang, H.L.; Zhang, E.P.; Chen, J.L.; Sun, J.M. Tectonic framework of North Qinling mountain and North Qilian mountain conjunction area in Early Paleozoic: A study of the evidences from strata and tectonic-magmatic events. Northwest. Geol. 2008, 41, 1-21, (In Chinese with English Abstract).

100. Mao, J.W.; Zhang, Z.H.; Jian, P.; Wang, Z.L.; Yang, J.M.; Zhang, Z.C. U-Pb zircon dating of the Yeniutan granitic intrusion in the western part of the North Qilian Mountains. Geol. Rev. 2000, 46, 616-620, (In Chinese with English Abstract).

101. Pan, G.T.; Xiao, Q.H.; Lu, S.N.; Deng, J.F.; Feng, Y.M.; Zhang, K.X.; Zhang, Z.Y.; Wang, F.G.; Xing, G.J.; Hao, G.J.; et al. Subdivision of tectonic units in China. Geol. China 2009, 36, 1-28, (In Chinese with English Abstract).

102. Pei, X.Z.; Sun, R.Q.; Ding, S.P.; Liu, H.B.; Li, Z.C.; Liu, Z.Q.; Meng, Y. LA-ICP-MS zircon U-Pb dating of the Yanjiadian diorite in the eastern Qilian Mountains and its geological significance. Geol. China 2007, 34, 8-16, (In Chinese with English Abstract). [CrossRef] 
103. Shi, R.D.; Yang, J.S.; Wu, L.C.; Wooden, J. First SHRIMP dating for the formation of the Late Sinian Yushigou ophiolite, North Qilian mountains. Acta Geol. Sin. 2004, 78, 649-657, (In Chinese with English Abstract). [CrossRef]

104. Su, J.P.; Hu, N.G.; Zhang, H.F.; Fu, G.M. Single-zircon U-Pb dating and geological significance of the Diaodaban granitic gneiss in the western segment of North Qilian mountains. Geol. Sci. Technol. Inf. 2004, 23, 11-14, (In Chinese with English Abstract). [CrossRef]

105. Xia, L.Q.; Xia, Z.C.; Xu, X.Y. Tectonic-volcanic Magmatic-mineralization Dynamics of the Northern Qilian Mountains; China Land Press: Beijing, China, 2001; pp. 1-105. (In Chinese)

106. Xia, X.H.; Song, S.G. Age of formation and tectonic environment of Jiugequan ophiolite, sourthern Gansu province, north Qilian mountains. Chin. Sci. Bull. 2010, 55, 1465-1473. (In Chinese) [CrossRef]

107. Xiang, Z.Q.; Lu, S.N.; Li, H.K.; Li, H.M.; Song, B.; Zheng, J.K. SHRIMP U- Pb zircon age of gabbro in Aoyougou in the western segment of the North Qilian mountains, China and its geological implications. Geol. Bull. China 2007, 26, 1686-1691, (In Chinese with English Abstract).

108. Yu, J.Y.; Li, X.M.; Ma, Z.P.; Sun, J.M.; Wang, J.Q. Chronological study of meta-acidic volcanics in Qingshuigou-Bailiugou orefield, Qilian county of Qinghai province. Adv. Earth Sci. 2010, 25, 55-60, (In Chinese with English Abstract).

109. Zeng, J.Y.; Yang, H.Y.; Wan, Y.S.; Liu, D.Y.; Wen, D.R.; Lin, Z.Q.; Dong, G.A. The discovery of records of neoproterozoic ( 775 Ma) magma activity in metamorphic complex of North Qilian Mountains: Evidence from SHRIMP zircon U-Pb dating. Chin. Sci. Bull. 2006, 51, 575-581. (In Chinese)

110. Zhang, L.Y.; Qu, X.M.; Xin, H.B. Geochemical characteristics, zircon U-Pb LA-ICP-MS ages of medium-acid dykes in the Huashugou iron-copper deposit, Jingtieshan orefield, and their geological significances. Geol. Rev. 2008, 54, 253-262, (In Chinese with English Abstract). [CrossRef]

111. Song, S.G.; Zhang, L.F.; Niu, Y.; Song, B.; Zhang, G.B.; Wang, Q.J. SHRIMP eclogite zircon dating and its tectonic significance in North Qilian mountains. Chin. Sci. Bull. 2004, 49, 592-595. (In Chinese) [CrossRef]

112. He, S.P.; Wang, H.L.; Chen, J.L.; Xu, X.Y.; Zhang, H.F.; Ren, G.M. Zircon U-Pb chronology of Longshan rock group by LA-ICP-MS and its geological significance. Acta Geol. Sin. 2006, 80, 1668-1675, (In Chinese with English Abstract).

113. He, Y.H.; Chen, L.; Sun, Y.; Li, H.P. Zircon chronology of Xinjie complex in Longxian county and its geological significance. J. Northwest Univ. Nat. Sci. Ed. 2005, 35, 135-137, (In Chinese with English Abstract).

114. Yu, S.Y. Composition, Metamorphism and Deforamation of Subduction-accretionary Complex in the North Qilian Mountain. Master's Thesis, Chinese Academy of Geological Science, Beijing, China, 2007. (In Chinese with English Abstract).

115. Zheng, R.G.; Zhang, J.; Xiao, W.J. Association of Permian gabbro and granite in the Langshan, southern Central Asian Orogenic Belt: Age, origin, and tectonic implications. Lithos 2019, 348, 105174. [CrossRef]

116. Zhou, H.; Zhao, G.C.; Han, Y.G.; Wang, B. Geochemistry and zircon U-Pb-Hf isotopes of Paleozoic intrusive rocks in the Damao area in Inner Mongolia, northern China: Implications for the tectonic evolution of the Bainaimiao arc. Lithos 2018, 314, 119-139. [CrossRef]

117. Liu, M.; Zhang, D.; Xiong, G.Q.; Zhao, H.T.; Di, Y.J.; Wang, Z.; Zhou, Z.G. Zircon U-Pb age, Hf isotope and geochemistry of Carboniferous intrusions from the Langshan area, Inner Mongolia: Petrogenesis and tectonic implications. J. Asian Earth Sci. 2016, 120, 139-158. [CrossRef]

118. Mo, N. Geochronology, Hf Isotope of Phanerozoic Granitoids in Baotou-Erenhot Area and Its Tectonic Implications. Master's Thesis, China University of Geosciences, Beijing, China, 2015. (In Chinese with English Abstract).

119. Zhang, Q.; Li, Y.H.; Chen, G.C.; Han, W.; Wang, J. Geochronology, Geochemistry, and Hf isotopic Compositions of the Late-Carboniferous Volcanic Rocks in Tongshengmao of Daqinshan Area, Inner Mongolia and Their Geological Implications. Geol. J. China Univ. 2018, 24, 160-171, (In Chinese with English Abstract).

120. Zhang, J.J. Magma Mixing Origin of Yamatu Granite in Nuoergong-Langshan Area, Western Margin of North China Craton: In-situ Zircon U-Pb, Hafnium Isotopic, Petrology and Geochemistry Evidences. Master's Thesis, China University of Geosciences, Beijing, China, 2012. (In Chinese with English Abstract).

121. Zhang, W.; Jian, P. SHRIMP dating of the Permian Guyang diorite-quartz diorite-tonalite suite in the northern margin of the North China Craton. Geol. China 2012, 39, 1593-1603, (In Chinese with English Abstract). 
122. Tian, J.; Teng, X.J.; Liu, Y.; Teng, F.; He, P.; Guo, S.; Wang, W.L. Petrogenesis and tectonic significance of the Early Carboniferous hornblende-gabbro and granodiorite in Langshan area, Inner Mongolia. Acta Petrol. Mineral. 2018, 37, 754-770, (In Chinese with English Abstract).

123. Liu, Y.; Wang, W.L.; Teng, X.J.; Guo, S.; Reng, F.; He, P.; Tian, J.; Duan, X.L. Geochemistry and Hf isotopes characteristics and geological significance of latest early permian granodiorite of Langshan area, Inner Mongolia. Adv. Earth Sci. 2019, 34, 366-381, (In Chinese with English Abstract).

124. Wang, L.; Wang, G.H.; Lei, S.B.; Chang, C.J.; Hou, W.R.; Jia, L.Q.; Zhao, G.M.; Chen, H.J. Petrogenesis of Dahuabei pluton from Wulashan, Inner Mongolia: Constraints from geochemistry, zircon U-Pb dating and Sr-Nd-Hf isotopes. Acta Petrol. Sin. 2015, 31, 1977-1994, (In Chinese with English Abstract).

125. Arkin, A.; Xie, G.; Zhang, J.; Qu, J.; Tian, R.; Zhao, H.; Li, F.; Li, T. Geochemistry, zircon U-Pb age and tectonic settings of pillow basalts in the Langshan area on the northern margin of the Alxa block, Inner Mongolia. Geol. Bull. China 2019, 38, 810-823, (In Chinese with English Abstract).

126. Zhao, Q.Y. Origin and Tectonic Setting of Late Paleozoic-Early Mesozoic Granites in Daqingshan District, Inner Mongolia. Ph.D. Thesis, Jilin University, Changchun, China, 2010. (In Chinese with English Abstract).

127. Tian, J.; Xin, H.T.; Teng, X.J.; Liu, Y.; Guo, S.; Teng, F.; He, P.; Wang, W.L. Carboniferous Triassic magmatism and its tectonic significance in Langshan area, Inner Mongolia. Earth Sci. 2019, 44, 206-219, (In Chinese with English Abstract). [CrossRef]

128. Liu, C.; Sun, L.L.; Wu, Q.; Zeng, F.G. Discovery of the Early Carboniferous Granite in Guyang, Inner Mongolia: Evidence from Zircon SHRIMP U-Pb Dating. Geol. J. China Univ. 2015, 21, 519-528, (In Chinese with English Abstract).

129. Jiao, Z. Late Paleozoic-Mesozoic Granites Origin and Its Tectonic Settings Analysis of Inner Mongolia Wula Mountain. Master's Thesis, East China Institute of Technology, Nan Chang, China, 2015. (In Chinese with English Abstract).

130. Liu, P.H.; Zou, L.; Tian, Z.H.; Ji, L.; Shi, J.R. Determination of Late Paleozoic metamorphic event in the Langshan area, western Inner Mongolia: New evidence from LA-ICP-MS zircon U-Pb dating of the Wulashan Group. Geol. Bull. China 2019, 38, 1691-1710, (In Chinese with English Abstract).

131. Gong, M. Determination and Geological Significance of Late Paleozoic Alkali-rich Intrusions Belt at the Northern Foot of Yinshan-Yanshan. Master's Thesis, China University of Geosciences, Beijing, China, 2019. (In Chinese with English Abstract).

132. Bai, X.H.; Xu, Z.Y.; Liu, Z.H.; Xin, H.T.; Wang, W.Q.; Wang, X.; Lei, C.C. Zircon U-Pb dating, geochemistry and geological significance of the Early Silurian plutons from the southeastern margin of the Central Asian Orogenic Belt. Acta Petrol. Sin. 2015, 31, 67-79, (In Chinese with English Abstract).

133. Liu, X.S.; Hou, Y.D.; Guo, Y.Q.; Ma, Y.P.; Cao, Q.; Bai, Y.B.; Su, H.B.; Li, J.; Wu, W.T.; Du, Y.J. Sedimentary Characteristics of He 8 Member of Upper Paleozoic in Eastern Ordos Basin and Its Control on High Quality Reservoir; PetroChina Changqing Oilfield Company: Xi'an, China, 2009; Volume 161. (In Chinese)

134. Luo, J.L.; Dong, W.P.; Liu, X.; Zhang, C.L.; Li, W.; Chang, S.; Jiang, L.; Guo, Y.F.; Wang, M.; Cheng, C. Source and Sedimentary Environment of Upper Paleozoic in Yanchang Exploration Area, Yan'an; Yanchang Oilfield Company Ltd.: Xi'an, China, 2012; Volume 106. (In Chinese)

135. Vermeesch, P. On the visualisation of detrital age distributions. Chem. Geol. 2012, 312, 190-194. [CrossRef]

136. Yu, S.Y.; Zhang, J.X.; Del Real, P.G.; Zhao, X.L.; Hou, K.J.; Gong, J.H.; Li, Y.S. The Grenvillian orogeny in the Altun-Qilian-North Qaidam mountain belts of northern Tibet Plateau: Constraints from geochemical and zircon U-Pb age and Hf isotopic study of magmatic rocks. J. Asian Earth Sci. 2013, 73, 372-395. [CrossRef]

137. Dong, Y.P.; Santosh, M. Tectonic architecture and multiple orogeny of the Qinling Orogenic Belt, Central China. Gondwana Res. 2016, 29, 1-40. [CrossRef]

138. Lu, S.N.; Chen, Z.L.; Li, H.H.; Hao, G.J.; Zhou, H.Y.; Xiang, Z.Q. Late Mesoproterozoic-early Neoproterozoic evolution of Qinling orogeny. Geol. Bull. China 2004, 23, 107-112, (In Chinese with English Abstract).

139. Song, S.G.; Niu, Y.L.; Su, L.; Zhang, C.; Zhang, L.F. Continental orogenesis from ocean subduction, continent collision/subduction, to orogen collapse, and orogen recycling: The example of the North Qaidam UHPM belt, NW China. Earth Sci. Rev. 2014, 129, 59-84. [CrossRef]

140. Davis, G.A.; Wang, C.; Zheng, Y.; Zhang, J.; Zheng, C.; Gehrels, G.E. The enigmatic Yinshan fold-and-thrust belt of northern China: New views on its intraplate contractional styles. Geology 1998, 26, 43-46. [CrossRef]

141. Zhang, S.H.; Zhao, Y.; Song, B.; Hu, J.M.; Liu, S.W.; Yang, Y.H.; Chen, F.K.; Liu, X.M.; Liu, J. Contrasting Late Carboniferous and Late Permian-Middle Triassic intrusive suites from the northern margin of the 
North China craton: Geochronology, petrogenesis, and tectonic implications. Bull. Geol. Soc. Am. 2006, 121, 181-200. [CrossRef]

142. Zhang, S.H.; Zhao, Y.; Song, B.; Yang, Z.Y.; Hu, J.M.; Wu, H. Carboniferous granitic plutons from the northern margin of the North China block: Implications for a late Palaeozoic active continental margin. J. Geol. 2007, 164, 451-463, (In Chinese with English Abstract). [CrossRef]

143. Wan, Y.S.; Liu, D.Y.; Dong, C.Y.; Xu, Z.Y.; Wang, Z.J.; Wilde, S.A.; Yang, Y.H.; Liu, Z.H.; Zhou, H.Y. The Precambrian Khondalite Belt in the Daqingshan area, North China Craton: Evidence for multiple metamorphic events in the Palaeoproterozoic era. Geol. Soc. Lond. Spec. Publ. 2009, 323, 73-97. [CrossRef]

144. Liu, L.; Liao, X.Y.; Wang, Y.W.; Wang, C.; Santosh, M.; Yang, M.; Zhang, C.L.; Chen, D.L. Early Paleozoic tectonic evolution of the North Qinling Orogenic Belt in Central China: Insights on continental deep subduction and multiphase exhumation. Earth Sci. Rev. 2016, 159, 58-81. [CrossRef]

145. Liu, Y.J.; Neubauer, F.; Genser, J.; Takasu, A.; Ge, X.; Handler, R. ${ }^{40} \mathrm{Ar} /{ }^{39} \mathrm{Ar}$ ages of blueschist facies pelitic schists from Qingshuigou in the Northern Qilian Mountains, western China. Isl. Arc 2006, 15, 187-198. [CrossRef]

146. Song, S.G.; Zhang, L.F.; Niu, Y.L.; Su, L.; Song, B.; Liu, D.Y. Evolution from Oceanic Subduction to Continental Collision: A Case Study from the Northern Tibetan Plateau Based on Geochemical and Geochronological Data. J. Petrol. 2006, 47, 435-455. [CrossRef]

147. Zhang, J.X.; Meng, F.C.; Wan, Y.S. A cold Early Palaeozoic subduction zone in the North Qilian Mountains, NW China: Petrological and U-Pb geochronological constraints. J. Metamorph. Geol. 2007, 25, 285-304. [CrossRef]

148. Zhang, Z.Q.; Liu, D.Y.; Fu, G.M. Isotopic Dating of Metamorphic Strata in the North Qinling Orogenic Belt; Geological Press: Beijing, China, 1994; pp. 1-191. (In Chinese)

(C) 2020 by the authors. Licensee MDPI, Basel, Switzerland. This article is an open access article distributed under the terms and conditions of the Creative Commons Attribution (CC BY) license (http://creativecommons.org/licenses/by/4.0/). 